\title{
Structure and Functional Analysis of Promoters from Two Liver Isoforms of CPT I in Grass Carp Ctenopharyngodon idella
}

\author{
Yi-Huan $\mathrm{Xu}^{1}{ }^{10}$, Zhi Luo ${ }^{1,2, *}$, Kun $\mathrm{Wu}^{1}{ }^{1}$, Yao-Fang Fan ${ }^{1}$, Wen-Jing You ${ }^{1}$ and Li-Han Zhang ${ }^{1}$ \\ 1 Key Laboratory of Freshwater Animal Breeding, Ministry of Agriculture, Fishery College, \\ Huazhong Agricultural University, Wuhan 430070, China; xuyihuan1989@163.com (Y.-H.X.); \\ wk901012@126.com (K.W.); fanyaofang@mail.dlut.edu.cn (Y.-F.F.); ywj0861@126.com (W.-J.Y.); \\ zhlh8175@126.com (L.-H.Z.) \\ 2 Collaborative Innovation Center for Efficient and Health Production of Fisheries, \\ Hunan University of Arts and Science, Changde 415000, China \\ * Correspondence: luozhi99@mail.hzau.edu.cn; Tel.: +86-27-8728-2113
}

Received: 7 October 2017; Accepted: 10 November 2017; Published: 13 November 2017

\begin{abstract}
Carnitine palmitoyltransferase I (CPT I) is a key enzyme involved in the regulation of lipid metabolism and fatty acid $\beta$-oxidation. To understand the transcriptional mechanism of $C P T I \alpha 1 b$ and CPT I $\alpha 2 a$ genes, we cloned the 2695-bp and 2631-bp regions of CPT I $\alpha 1 b$ and CPT I $\alpha 2 a$ promoters of grass carp (Ctenopharyngodon idella), respectively, and explored the structure and functional characteristics of these promoters. CPT I $11 b$ had two transcription start sites (TSSs), while CPT I $\alpha 2 a$ had only one TSS. DNase I foot printing showed that the CPT I $\alpha 1 b$ promoter was AT-rich and TATA-less, and mediated basal transcription through an initiator (INR)-independent mechanism. Bioinformatics analysis indicated that specificity protein $1(\mathrm{Sp} 1)$ and nuclear factor $\mathrm{Y}$ (NF-Y) played potential important roles in driving basal expression of CPT I $\alpha 2 a$ gene. In HepG2 and HEK293 cells, progressive deletion analysis indicated that several regions contained cis-elements controlling the transcription of the CPT I $\alpha 1 b$ and CPT I $\alpha 2 a$ genes. Moreover, some transcription factors, such as thyroid hormone receptor (TR), hepatocyte nuclear factor 4 (HNF4) and peroxisome proliferator-activated receptor (PPAR) family, were all identified on the CPT I $\alpha 1 b$ and CPT I $2 a$ promoters. The TR $\alpha$ binding sites were only identified on CPT I $\alpha 1 b$ promoter, while TR $\beta$ binding sites were only identified on CPT I $\alpha 2 a$ promoter, suggesting that the transcription of CPT I $\alpha 1 b$ and CPT $I \alpha 2 a$ was regulated by a different mechanism. Site-mutation and electrophoretic mobility-shift assay (EMSA) revealed that fenofibrate-induced PPAR $\alpha$ activation did not bind with predicted PPAR $\alpha$ binding sites of CPT I promoters. Additionally, PPAR $\alpha$ was not the only member of PPAR family regulating CPT I expression, and PPAR $\gamma$ also regulated the CPT I expression. All of these results provided new insights into the mechanisms for transcriptional regulation of CPT I genes in fish.
\end{abstract}

Keywords: Ctenopharyngodon idella; carnitine palmitoyltransferase I; promoters; peroxisome proliferator-activated receptor; transcriptional regulation

\section{Introduction}

Lipids are the major sources of metabolic energy in fish [1]. Body lipid composition results from the balance among deposition of dietary lipids, de novo synthesis of fatty acids and oxidation of fatty acids. While the relations between food intake and lipid deposition as well as nutritional control of fatty acid synthesis are well documented [1], fatty acid catabolism has received little attention. The $\beta$-oxidation of fatty acids plays a critical role in the production of energy, and most oxidation occurs in the mitochondria [2]. Carnitine palmitoyltransferase I (EC.2.3.1.21; CPT I), located in outer 
membranes of mitochondria, controls the flux through $\beta$-oxidation and is the main regulatory enzyme of fatty acid oxidation [3,4]. The studies about the structure and transcriptional regulation of CPT I gene are useful for the understanding of the $\beta$-oxidation in fish. In mammals, three CPT I isoforms encoded by distinct genes have been discovered: a liver isoform (CPT I $\alpha$ ) [5], a muscle isoform (CPT I $\beta$ ) [6], and a brain isoform (CPT Ic) [7]. In fish, however, due to fish-specific genomic duplication event, various CPT I isoforms have been cloned. For example, three $\alpha$-copies and one $\beta$-copy of CPT I was obtained in yellow catfish Pelteobagrus fulvidraco [8] and seven complete CPT I cDNA sequences (CPT I $\alpha 1 a-1 a, C P T$ I $\alpha 1 a-1 b, C P T$ I $\alpha 1 a-1 c$, CPT I $\alpha 1 a-2$, CPT I $\alpha 2 a, C P T$ I $\alpha 2 b 1 a, C P T$ I $\beta$ ) and a partial cDNA sequence (CPT I $\alpha 2 b 1 b)$ were cloned in goby Synechogobius hasta [9]. In grass carp, the complete cDNA sequences of three CPT I $\alpha$ genes (CPT I $1 a, C P T I \alpha 1 b$ and CPT I $\alpha 2 a$ ) and one CPT I $\beta$ gene isoforms have successfully been cloned $[10,11]$. Although these isoforms of CPT I gene can express CPT I protein which catalyzes the same reaction, they have different properties [8]. For example, McGarry and Brown [12] pointed out that mammalian CPT I $\beta$ had a much lower IC50 and higher Km for carnitine than CPT I $\alpha$ (from [8]). Lineage- and species-specific genome duplication events can lead to increased diversity in protein regulation and function. At present, while the characteristics of CPT I gene and structure prediction as well as its enzyme kinetics are well documented in fish $[8,9,11,13,14]$, mechanisms involving the transcriptional regulations of CPT I gene received no attention.

Considering the importance of CPT I in regulating fatty acid oxidation, it is very important and meaningful to explore the regulatory mechanism of CPT I mRNA expression. At present, most studies on the mRNA expression and/or activity of CPT I isoforms in fish involve the response to either dietary or hormonal treatments [15-19]. However, expression of eukaryotic genes is controlled at the level of transcription initiation. Promoters, which contain cis-acting sequences bound by a wide variety of regulatory factors, control the expression of individual genes. Therefore, it is very important to analyze the structure and function of CPT I promoter, which helps to understand the regulatory mechanism of CPT I itself. At present, the promoter of the CPT I $\alpha$ gene has been obtained only in mammals [20,21], but not in fish. The present study hypothesizes that significant differences exist in structure and function of CPT I promoters between fish and mammals.

Lipid metabolism is closely controlled by diverse regulatory systems involving many transcription factors. Peroxisome proliferator-activated receptors (PPARs), which belong to ligand-dependent transcription factors, regulate the expression of various genes involved in lipid metabolism [22,23]. Among the PPAR family member, PPAR $\alpha$ plays crucial roles in the catabolism of fatty acids by increasing the expression of key lipolytic enzymes (also CPT I) [24,25]. Studies demonstrated that the PPAR $\alpha$ mRNA expression was positively correlated to CPT I mRNA expression $[14,26]$. Further investigation indicated that PPAR $\alpha$ stimulated through a peroxisome proliferator-responsive element (PPRE) in the first and second intron of the human and rat CPT I $\alpha$ genes, respectively $[27,28]$. PPAR $\gamma$, involved in the regulation of lipogenesis and lipid storage, preferentially control the transcription of genes in triglyceride synthesis [29]. In an earlier study, Chen et al. [30] found that mRNA expression of PPAR $\gamma$ was positively correlated with CPT I expression, suggesting a potential regulation of PPAR $\gamma$ on CPT I expression. At present, although several evidences suggested that CPT I $\alpha$ was a target gene for PPAR [27-29], a lack of knowledge regarding the DNA sequence responsible for this predicted regulatory mechanism has left this a controversial issue. Thus, considering the importance of PPARs in lipid metabolism, it is very important to explore the regulation of CPT I expression by PPARs.

Grass carp (Ctenopharyngodon idella) was an important herbivorous freshwater fish widely farmed all over the world because of its good taste and high market price. Its aquaculture yield amounted to 6 million metric tons in China in 2016. In some countries of European and Northern America, grass carp were used to control aquatic plants because of their aggressive feeding on vegetation [31]. At present, grass carp is considered a good model for the study of lipid metabolism because it stores excess fat in liver and adipose tissues under intensive aquaculture. Recently, the draft genome of the grass carp has been released, which is considered a convenient tool for identifying genomic structure of genes involved in lipid metabolism [32]. In the present study, we characterized CPT I $\alpha 1 b$ and CPT 
$I \alpha 2 a$ promoters in grass carp. Their transcriptional regulation by peroxisome proliferators was also explored. These studies will provide new insights into the transcriptional regulatory mechanism of CPT I genes in fish.

\section{Results}

Studies indicated that, compared with other isoforms, mRNA levels of CPT I $1 b$ and CPT $1 \alpha 2 a$ were predominant in the liver $[10,11]$. Therefore, CPT I $\alpha 1 b$ and CPT $1 \alpha 2 a$ were considered as liver isoforms. To investigate their transcriptional regulatory mechanism, for the first time, we cloned the sequences of promoters of the two liver isoforms (CPT I $\alpha 1 b$ and CPT I $\alpha 2 a)$, and explored their functional characteristics in fish.

\subsection{Identification of Transcription Start Site (TSS)}

In the present study, the $2695 \mathrm{bp}$ of CPT I $1 \mathrm{~b}$ promoter and $2631 \mathrm{bp}$ of CPT I $\alpha 2 a$ promoter were cloned and submitted to an online transcription factor database (MatInspector) for sequence analysis. RNA ligase-mediated rapid amplification of $5^{\prime}$ cDNA ends (RLM- $5^{\prime}$ RACE) was performed to identify the TSS of CPT I $\alpha 1 b$ and CPT I $2 a$ promoters. This amplification generated two different TSSs of $C P T I \alpha 1 b$ which approximately corresponded to the alternative $5^{\prime}$ splice variants of $C P T I \alpha 1 b$ mRNA, and one TSS of CPT I $\alpha 2 a$ without alternative $5^{\prime}$ variant. The first nucleotide of the CPT I $\alpha 1 b$ gene, mapped to the most upstream position from the grass carp liver cDNA library, was arbitrarily designated as $+1^{\prime}$ and the alternative $5^{\prime}$ splicing site was designated as +1 (Figure 1A,B). The first nucleotide of the CPT I $\alpha 2 a$ gene was designated as +1 (Figure 1C).

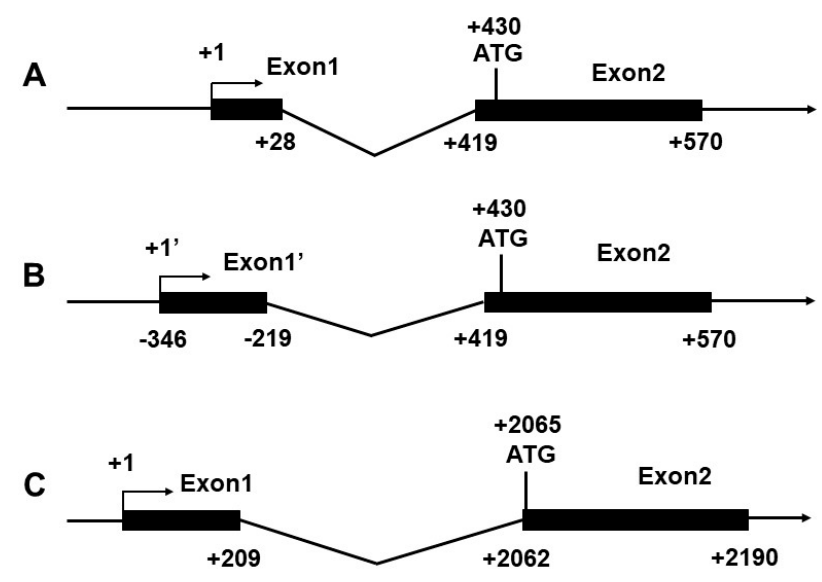

Figure 1. A map of the first two exons in the CPT I $\alpha 1 b$ and CPT I $2 a$ genes was shown. Exons were denoted by black rectangles, introns by a fold line and transcriptional direction (5'-3') by an arrow line. The initiation codon (ATG) in exon 2 represented the start site of protein translation. Numbers were relative to the distance from transcription start site $(+1)$. (A) structure of transcription start site (TSS) of CPT I $\alpha 1 b$ gene (B) structure of alternative splicing transcription start site (TSS') of CPT I $1 b$ gene (C) structure of transcription start site of CPT I $2 a$ gene.

\subsection{DNase I Foot Printing Assay of Core Promoter of CPT I $\alpha 1 b$}

Figure 2A showed the core region of CPT I $\alpha 1 b$ promoter from $-268 \mathrm{bp}$ to $+37 \mathrm{bp}$ containing transcription start site (TSS1). Predicted TATA-box was located between $148 \mathrm{bp}$ and $167 \mathrm{bp}$ of the FAM-labeled fragment, and the electropherograms around this region presented similar peak patterns between control group ( $0 \mu \mathrm{g}$ nuclear proteins, $20 \mu \mathrm{g}$ bovine serum albumin, BSA) and DNase I digested group $(10 \mu \mathrm{g}$ nuclear proteins, $10 \mu \mathrm{g}$ BSA). In contrast, the region between $290 \mathrm{bp}$ and $360 \mathrm{bp}$ presented different peak patterns between control group and DNase I digested group, where the initiator (INR) was located. Figure $2 \mathrm{~B}$ showed the core region of $C P T I \alpha 1 b$ promoter from $-581 \mathrm{bp}$ to $-236 \mathrm{bp}$ 
containing alternative transcription start site (TSS2). Predicted TATA-box on this fragment was located between $327 \mathrm{bp}$ and $343 \mathrm{bp}$ of the FAM-labeled fragment, and the electropherograms on this region were similar between control group ( $0 \mu \mathrm{g}$ nuclear proteins, $20 \mu \mathrm{g}$ BSA) and DNase I digested group (10 $\mu \mathrm{g}$ nuclear proteins, $10 \mu \mathrm{g}$ BSA). In contrast, the different peak patterns were discovered at the region between $285 \mathrm{bp}$ and $310 \mathrm{bp}$, where the INR was located. Taken together, these indicated that the INR on the promoter was sufficient for the transcription initiation of CPT I $\alpha 1 b$ gene.

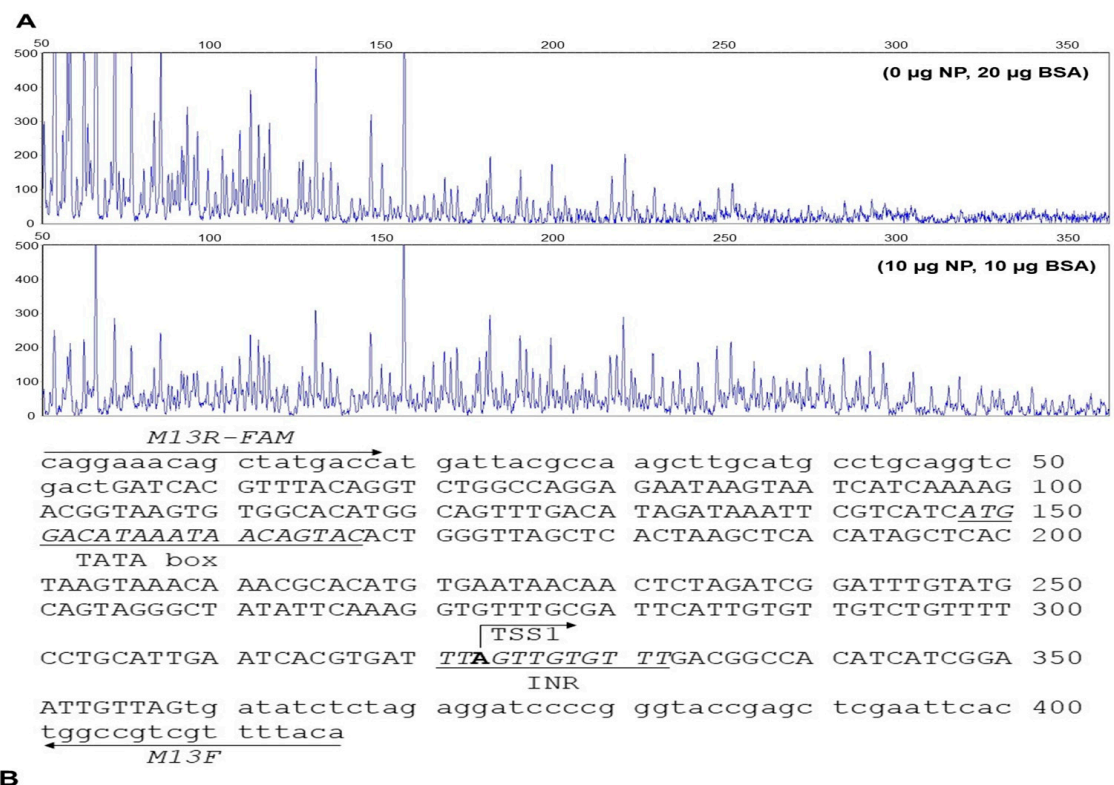

B

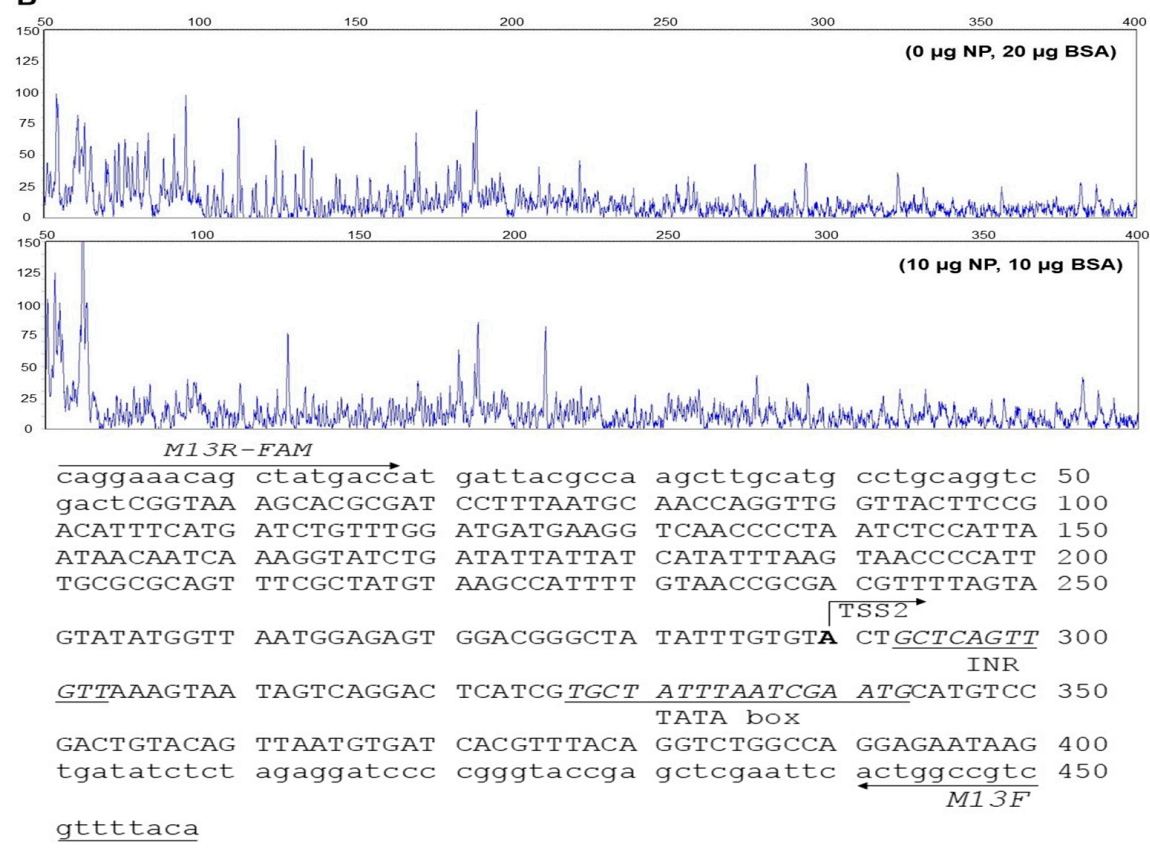

Figure 2. DNase I foot printing assay of proximal promoter of $C P T I \alpha 1 b$. (A) 303-bp proximal promoter region of $C P T I \alpha 1 b$ (B) 346-bp proximal promoter region of CPT $I \alpha 1 b$. The sequence used for FAM-labeled probe was presented, based on the result of DNase I foot printing. Putative binding sequence was underlined and italicized with labels. Capital letters indicate the coding sequence of proximal promoter region of CPT I $\alpha 1 b$, and lowcase letters indicate the partial sequence of pMD-19T vector. The primer sequences used for DNase I foot printing assay M13F and M13R-FAM were labeled by arrows. 


\subsection{Sequence Analysis of the CPT I $\alpha 1 b$ and CPT I $\alpha 2 a$ Promoters}

Several putative core promoter elements close to the TSS on the CPT I $1 b$ promoter, including two TATA-box (TBP) located from $-160 \mathrm{bp}$ to $-176 \mathrm{bp}$ and from $-293 \mathrm{bp}$ to $-309 \mathrm{bp}$, and two initiator (INR) located at $-2 \mathrm{bp}$ to $+10 \mathrm{bp}$ (TSS1) and $-333 \mathrm{bp}$ to $-343 \mathrm{bp}$ (TSS2), were identified (Figure 3). Meanwhile, on the core region of CPT I 2 2a promoter, three CCAAT-box (NF-Y) were identified, located at $-46 \mathrm{bp}$ to $-60 \mathrm{bp},-146 \mathrm{bp}$ to $-160 \mathrm{bp}$ and $-165 \mathrm{bp}$ to $-179 \mathrm{bp}$, respectively. Besides, two GGGCGG-box (Sp1), located at $-13 \mathrm{bp}$ to $-29 \mathrm{bp}$ and $-127 \mathrm{bp}$ to $-143 \mathrm{bp}$, were also identified on the core promoter of CPT I $\alpha 2 a$ (Figure 4). Some relevant TFBSs of CPT I $\alpha 1 b$ and CPT I $\alpha 2 a$ were presented in Figures 3 and 4. There were two thyroid hormone receptor $\alpha(\mathrm{TR} \alpha)$ binding sites on the CPT I $\alpha 1 b$ promoter at the position $-1070 \mathrm{bp}$ to $-1094 \mathrm{bp}$ and $-2067 \mathrm{bp}$ to $-2091 \mathrm{bp}$, and three thyroid hormone receptor $\beta$ (TR $\beta$ ) binding sites on the CPT I $\alpha 2 a$ promoter, at the position $-39 \mathrm{bp}$ to $-63 \mathrm{bp},-1103 \mathrm{bp}$ to $-1127 \mathrm{bp}$ and $-1331 \mathrm{bp}$ to $-1355 \mathrm{bp}$, respectively. In addition, we discovered one HNF4 binding site on the CPT I $\alpha 1 b$ promoter, located at $-2379 \mathrm{bp}$ to $-2403 \mathrm{bp}$, one HNF4 binding site on the CPT I $2 a$ promoter, located at the position $-406 \mathrm{bp}$ to $-430 \mathrm{bp}$, and one HNF4 $\alpha$ binding site on the CPT I $\alpha 2 a$ promoter, located at the position $-2587 \mathrm{bp}$ to $-2611 \mathrm{bp}$. Moreover, analysis using MatInspector database revealed two PPAR binding sites on the CPT I $1 b$ promoter and four PPAR binding sites on the CPT I $\alpha 2 a$ promoter. Among these sites, one PPAR $\alpha / R X R$ binding site located at the position $-1814 \mathrm{bp}$ to $-1836 \mathrm{bp}$ and one PPAR $\gamma$ binding site located at the position $-1719 \mathrm{bp}$ to $-1741 \mathrm{bp}$ were predicted on the CPT I $\alpha 1 b$ promoter. Meanwhile, there were four important binding sites of transcriptional factors on the CPT I $\alpha 2 a$ promoter, distributed at the position -1939 bp to -1961 $\mathrm{bp}$ (PPAR $\alpha /$ RXR binding site), $-1179 \mathrm{bp}$ to $-1201 \mathrm{bp}$ (PPAR $\gamma$ binding site), $-1104 \mathrm{bp}$ to $-1136 \mathrm{bp}$ (PPAR $\gamma$ binding site) and $-1044 \mathrm{bp}$ to $-1066 \mathrm{bp}$ (PPAR $\gamma$ binding site).

AAGCAAGAAG GCAATAGGGT GACCCATGTA AACCTAATCT GAAATTTAAA TGAGGATTGA GCCAGTAAAA CTCAGATAAA CAACATTTCA AATTCGGACC -2596 ATTCTCTGTG GCATTGCAAG TATCTCCGGC AAATCCCTCA GCACAGATGC AGAAGAAGGG ATCTTCTCCA ATGCCAGTCA CACATGTCCC TCCGTTGTGA -2496 CACAGGTTCA CCTTGCAGTA ATCTCCTATA GAGACACACA TAAGCAGGA TGAATGGAAT TACAAAGATT AGACTGGAAT TAGTTCTTAT TIEATAATTT -2396 HNF4

GGCAATGGAC AGAGTGGCC TGCATATTAA GCTTCGAGA ATACAAAGGA GTAAGAAGCG CTTTTCACGC TTCTGAACAg GATCAGGAGA GTACAAAAGA -2296 TAAGAGATGT GAGCAGCATA GCCAATGTGT ATGTTGAATG AACTTTCGAA AGCTGATGTA TACTTTTCAA GGATGGGAAA GATTCTATGA TATAAGTGAA -2196 TTTATGAAAA AGAGCTTGAA TTGTGATAAC TGTGTGCGTA TGAGTGCACA AAATATATCG GAAGCAGTCA TAATAAAACA AAACAGACAC CTAATTAAAT -2096
TRa GCCECTCATG TTCTGTTTAG GAAGCCTCA G CATTCATTGT GCTTTATTCT GGCTGAACAA CATGTTAGGA TCAAAAAGAG GCATGAACAG AACGCAAGAA -1996 CATGAAATGC TCTAAGGCAC AAGTTGATGT GTGAAACGTT ACACAACATG CTTCCTGAGA AGCTGGGAGA TTTGCCCTCT GAGCTCATTA AGATTACATG -1896 TAGAGGTTAA GACGGGCTTC TTTGAATATG CTTGAGCAAG AAATTAAAGg CACTTTTCTT AAGCAACTTT GCACTGATTT ACTTTCCAGA ATTTTGTAGT -1796 TGTGAGTCAT ATTATCCAGT GGAGTGCATA TCCCTTTCCA CCTCCCTGTA GTGGATTTGT TCTTTCCCCC AATGGCCCGA CATCTCAGTA TCATCTGGGT -1696 GGTTAACACT TATTGAGATA CACTCTGTAT GAAATTCATC TTTATTCCAT TTAACAAGAA AATATAATAA TTTGGATAGA ATAAACAGTA TATAATGAAT -1596 AAGATAAATA AAGAGAGATC ATGCAAAATG TTAATTTAAA TGTTAACTGA TGGCTTTTGT TACTTGATCA AAACTCTCTC CTACTTATAT GGCCAGTAAG -1496 AGAAATACAA GATTGTCTCA AATGGATTGA AGGCAAATCT GTGAAATGTT CAGTAACCAC AGATAAACTC CTTCCCACAA TAAGAAACAT TCACTATTAA - 1396 AGTACTGTAA TACTTTTGTT TGCTGAATCA TATATAGGCC CATGTAACAG ATTAAAGGAT GTACTAACTA CTGCAAAAAA GTAAACCTAG GTAAAATTAT -1296 TTAAATGACT AATTTTAAGC TCAAACTCTT TTAACTACAG TAAAGCAATG ACACTTTAGT AATGACACTG ATGTATTTAG TAGGGTTGGA CTGGAAAAAg - 1196 AGCATTAAAT AAAAAGCACT AAAAATGTAC TAAGAATATA AGATGTTACT CACCATTCAC AGTATAAATG CTGCAAATGA CTAAACTGAC AAAAACTATT -1096 TR $\alpha$

ATACAGGACC GAGTAAGGTT CCGGGTCTTC ATATTGGTAC TCTGTTTCTC AAGTACCGGA GCGTTTTCTT TACCGCTAGC TGCTCCTGAC GTCATCCTCA - 996 AACGTGGAGC AGCTAGACGC GCTCAAGCAC AGGGCACGCG CACCGTTTAC GCGCACGGAT CAGCTATTGC AAGATCTGTT GTATTGTCAG ATTATAACGA -896 AACGTGGAGC AGCTAGACGC GCTCAAGCAC AGGGCACGCG CACCGTTTAC GCGCACGGAT CAGCTATTGC AAGATCTGTT GTATTGTCAG ATTATAACGA -896
CTCGATACAA TTGAAAGTAT GCGATTAAAA CAGAACTGTC AAAGTAAAGG TATTATGTAG ACGTGTTTC CGGATGTTGT GTTGAACTGT TAAAATAATC -796 TGTATTTTGT GGAAATTTTC TATTACATTA GAAACTCCCG AAATTTGGCC AGTTTAGCAA TCCTATTATC CCCTACTAAA AGTCCTTAGT AAGCATCCCC -696 TATGTGTTGT TAAAAACATG CCATGTTTTT GTGTGTATAT CTTCTCAGCG TGACTGAAGA AATTTTTGCA GCAGGCAGAA CGTCCACTCA GCATTCACTT -596 CCGTGTTGG TACCCGGTAA AGCACGCGAT CCTTTAATGC AACCAGGTTG GTTACTTCCG ACATTTCATG ATCTGTTTGG ATGATGAAGg TCAACCCCTA -496 ATCTCCATTA ATAACAATCA AAGGTATCTG ATATTATTAT CATATTTAAG TAACCCCATT TGCGCGCAGT TTCGCTATGT AAGCCATTTT GTAACCGCGA - 396 CGTTTTAGTA GTATATGGTT AATGGAGAGT GGACGGGCTA TATTTGTGTA CTGCTCAGTT GTTAAAGTAA TAGTCAGGAC TCATCGTGCT ATTTAATCGA -296 TSS2 TATA box

ATGCATGTCC GACTGTACAg TTAATGTGAT CACGTTTACA GGTCTGGCCA GGAGAATAAg TAATCATCAA AAGACGGTAA GTGTGGCACA TGGCAGTTTG -196 ACATAGATAA ATTCGTCATC ATGGACATAA ATAACAGTAC ACTGGGTTAG CTCACTAAGC TCACATAGCT CACTAAGTAA ACAAACGCAC ATGTGAATAA - 96 TATA box

TSS1

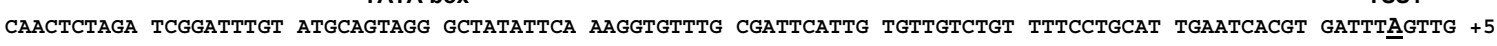
TGTTTGACGG CCACATCATC GGAATTGTTA G +36

Figure 3. Nucleotide sequence of grass carp CPT I $\alpha 1 b$ promoter. +1 denoted the transcription start site (TSS1) obtained from RLM-5'RACE experiment. TSS2 presented another transcription start site $\left(-346\right.$, TSS $\left.^{\prime}\right)$. Numbers indicated the distance from TSS1. The highlighted sequences show putative transcription factor binding sites. 


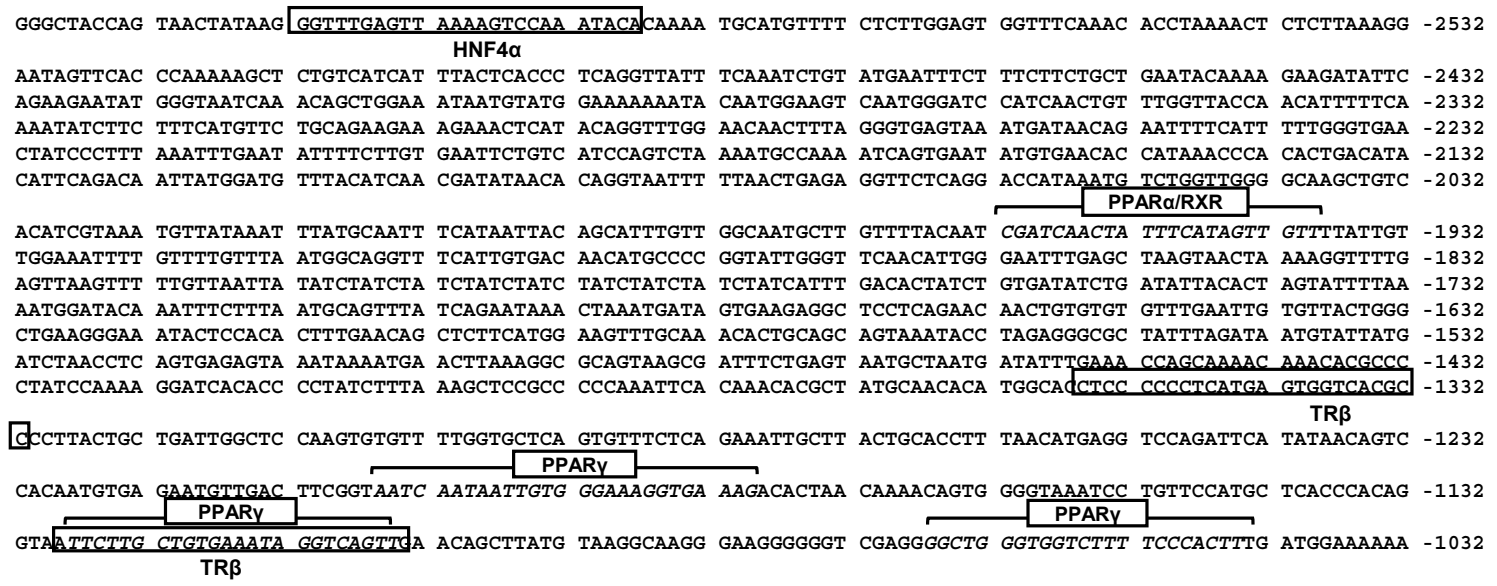
TCTGTGGTGT CTGTAAGCAG CACACGAGAC AGGAGTAGCG AACTTCATCC ATTTTGTTCA CTTCCATTCT CACACATTAC ATCAGAACGA AACAATTCAA -932 CAGTTTAGAC TTCCTCTTTT AAAATAGTAG TCCCAAAAAA ATTCACTCAT GGACACAACA AAATGAATCC TGGAAAATCC TTAAGGAGGA TTAACAGCAA - 832 AACACAACCA ATCTGTGCTA GTAGTACTAT AACTTTAGGC TATAGCACTT TGTAAAACAG AAGACATGTA TGTGTACTGA TAATTTGACA CTTTTTTTGT - 732 CCGGATCTGT TATTCAAAAT TACATTATTA TACAGTATTT ATGTATTTTT ATTATACAGT GACTTGAATA CTTGTAAAAG TAATTTTAAT AGTTAGTTTT - 632 TTTGTATTTG TTGTAAAGAT GTTTTACCTT GAAATGGAAA AACGTTTCAT AAAATAAAGA GTTTTGCACA CCCACATAGA TTTAAGGTGC AAGGAAAGTA -532 GTTAAAACGT TATAAATGTC TAATGACTAA TACTTTAACA TTATGTGAAC ATTTAAACTA TTTATATTTT AAAATATTCT CCTTTATATG ATCTCAGACA -432 GTTAAAACGT TATAAATGTC TAATGACTAA TACTTTAACA TTATGTGAAC ATTTAAACTA TTTATATTTT AAAATATTCT CCTTTATATG ATCTCAGACA -432
HNF4 TCATTATTTG TCTTTGTACC GCATAGCCTA TGTAAAGAGA AAGAATAAGA AACATCTAAG TAAAAATGAA TTTACAGAAT AAGATTATAT ATGAACTAAA - 332 TTGATCACAT AACCATAGTA GAGGCAGTAG CGGAAGTGAT TTTGCACGAA TATTTACTTC TGCTTGATAA TAACACTAAA ATGTTTATTT TATACTCCTC -232 GTTCCGCACC CATGATCAAA CTGTAAGCCA TGTCACTGCT GCCTGTCCCT AATCTTTGAT TGGCAGCCGT GACATCCAAT CACAGCGAAG TTTCCCGCCC -132

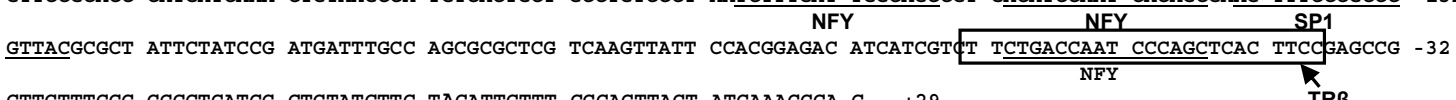
CTTGTTTCCC GCCCTCATCG CTGTATCTTC TACATtCTtT CGCACtTAGT ATCAAAgGCA C +29 SP1 TSS

Figure 4. Nucleotide sequence of grass carp CPT I $\alpha 2 a$ promoter. +1 denotes the TSS obtained from RLM-5'RACE experiment. Numbers present distance from TSS. The highlighted sequences show putative transcription factor binding sites.

\subsection{Deletion Assay of the CPT I $1 \mathrm{~b}$ and CPT I 2 a Promoter}

Deletion analysis of CPT I $\alpha 1 b$ and CPT I $\alpha 2 a$ promoters was presented in Figure 5. The reporter activity for each serial deletion was compared with the activity of pGl3-basic vector, and the pGl3-basic was chosen as the baseline. Figure 5A showed the result of deletion assay of the CPT I $\alpha 1 b$ promoter sequence from $-2695 \mathrm{bp}$ to $-86 \mathrm{bp}$ in HepG2 cells. Deletion of the region from $-2276 \mathrm{bp}$ to $-2695 \mathrm{bp}$ significantly increased the relative luciferase activity of the promoter. Subsequent deletion to $-1716 \mathrm{bp}$ significantly decreased the relative luciferase activity. Deletion of the sequence from $-581 \mathrm{bp}$ to $-1716 \mathrm{bp}$ showed no significant effect, whereas deletion of the sequence from $-581 \mathrm{bp}$ to $-86 \mathrm{bp}$ significantly decreased the relative luciferase activity. Figure 5B showed the result of deletion assay of the CPT I $\alpha 1 b$ promoter in HEK293 cells. Deletion of the sequence from $-2695 \mathrm{bp}$ to $-2276 \mathrm{bp}$ significantly increased the relative luciferase activity, and the sequence deletion from $-2276 \mathrm{bp}$ to $-1716 \mathrm{bp}$ significantly reduced the activity. Subsequent deletion to $-581 \mathrm{bp}$ presented no significant effects on the relative luciferase activity. The sequence deletion from $-581 \mathrm{bp}$ to $-86 \mathrm{bp}$ significantly decreased the relative luciferase activity.

Figure $5 \mathrm{C}$ presented the result of deletion assay of the CPT I $\alpha 2 a$ promoter sequence from $-2631 \mathrm{bp}$ to $-97 \mathrm{bp}$ in HepG2 cells. The relative luciferase activity of CPT I $2 a$ promoter showed no significant difference from $-2631 \mathrm{bp}$ to $-1646 \mathrm{bp}$. Deletion of the sequence from $-1646 \mathrm{bp}$ to $-1304 \mathrm{bp}$ significantly increased the relative luciferase activity. Subsequent deletion to $-848 \mathrm{bp}$ presented no significant effects on the relative luciferase activity. Deletion of the sequence of $-848 \mathrm{bp}$ to $-428 \mathrm{bp}$ and $-428 \mathrm{bp}$ to $-97 \mathrm{bp}$ significantly decreased the relative luciferase activity. Figure 5D showed the result of deletion assay of CPT I $\alpha 2 a$ promoter in HEK293 cells. Deletion of the sequence from $-2631 \mathrm{bp}$ to $-1165 \mathrm{bp}$ presented no significant effects on the relative luciferase activity. All of these sequence deletions from $-1165 \mathrm{bp}$ to $-848 \mathrm{bp},-848 \mathrm{bp}$ to $-428 \mathrm{bp}$ and $-428 \mathrm{bp}$ to $-97 \mathrm{bp}$ significantly decreased the luciferase activity. 


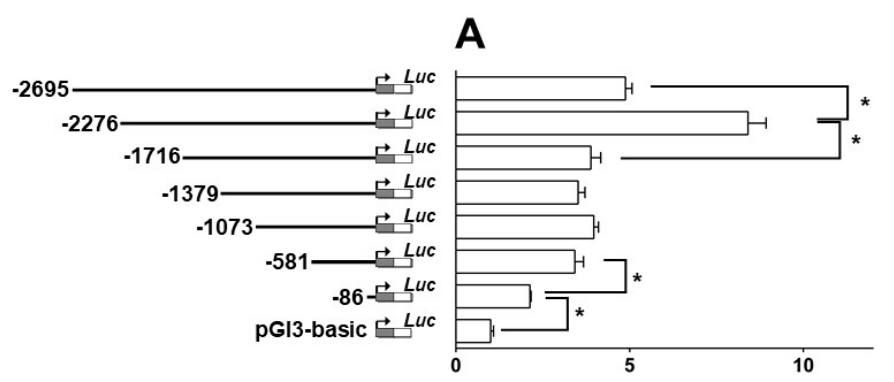

C

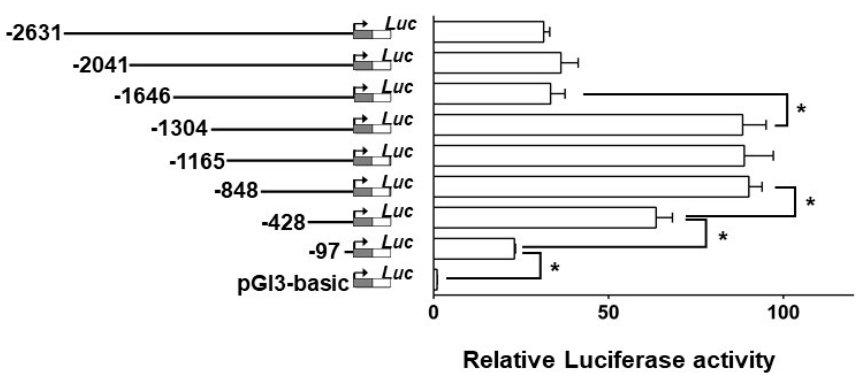

B

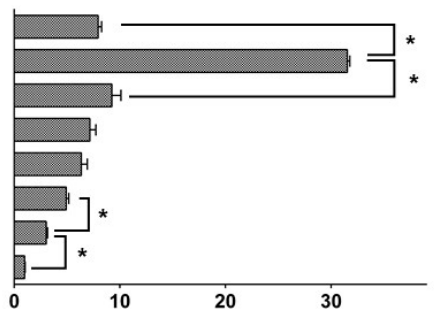

D

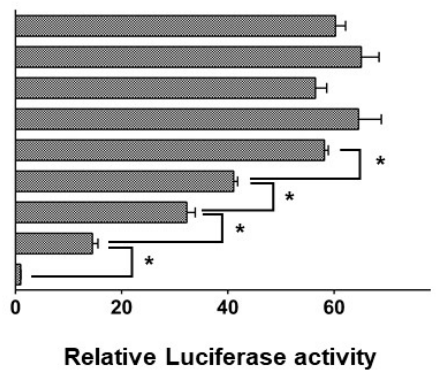

Figure 5. $5^{\prime}$ Unidirectional deletion analysis of the CPT I $\alpha 1 b$ and CPT I $\alpha 2 a$ promoter regions for grass carp. Schematic diagrams of truncated promoters were shown at the left panel. The corresponding luciferase reporter assay results were shown in the right panel. Promoter activity of constructs is presented with the values of relative light unit. A series of plasmids containing $5^{\prime}$ unidirectional deletions of the CPT I $\alpha 1 b$ promoter region fused in frame to the luciferase gene were transfected into HepG2 cells (A) and HEK293 cells (B), and a series of plasmids containing $5^{\prime}$ unidirectional deletions of the CPT I 2 2a promoter region were transfected into HepG2 cells (C) and HEK293 cells (D). Values represent the ratio between firefly and renilla luciferase activities, normalized to the control plasmid pGl3-Basic. Results were expressed as the mean \pm SEM of three independent experiments (Student's $t$-test, $\left.{ }^{*} p<0.05\right)$.

\subsection{Site-Mutation Analysis of PPAR Binding Sites}

Site-mutation analysis was used to evaluate the contribution of each PPAR binding site to the basal expression of the grass carp CPT I $1 b$ and CPT I $2 a$ genes in HepG2 cells (Figure 6). The disruption of the -1814 / -1836 PPAR $\alpha$ binding site did not change the relative luciferase activity against the wild-type pGl3-CPTI $\alpha 1 b-2276$, and disruption of the -1814 / -1836 PPAR $\alpha$ binding site did not influence the fenofibrate-induced change of luciferase activity, indicating that -1814 / -1836 PPAR $\alpha$ binding site did not contribute to the transcriptional response of CPTI $\alpha 1 b$ gene to fenofibrate (Figure 6A). The disruption of the $-1939 /-1961$ PPAR $\alpha$ binding site significantly up-regulated the relative luciferase activity against the wild-type pGl3-CPTI $\alpha 2 a-2041$. In contrast, disruption of the -1939 /-1961 PPAR $\alpha$ binding site did not influence the fenofibrate-induced change of luciferase activity induced, suggesting that the -1939 / -1961 sequence did not contribute to the transcriptional response of CPTI $\alpha 2 a$ gene to fenofibrate. We also disrupted each PPAR $\gamma$ binding site by site-directed mutagenesis in the context of the pGl3-CPTI $\alpha 1 b-2276$ and pGl3-CPTI $\alpha 2 a-1304$ vectors, respectively; meantime, three double mutants and one triple mutant of PPAR $\gamma$ binding site were produced on the pGl3-CPTI $\alpha 2 a-1304$ vector (Figure 6B). The disruption of the $-1719 /-1741$ PPAR $\gamma$ binding site did not change the relative luciferase activity against the wild-type pGl3-CPTI $\alpha 1 b-2276$, and disruption of the $-1719 /-1741$ PPAR $\gamma$ binding site did not influence the pioglitazone-induced change of luciferase activity, suggesting that $-1719 /-1741$ PPAR $\gamma$ binding site did not contribute to the transcriptional response of CPTI $\alpha 1 \mathrm{~b}$ gene to pioglitazone. Disruptions of the PPAR $\gamma$ binding sites on pGl3-CPTI $\alpha 2 \mathrm{a}-1304$ vectors showed that the $-1044 /-1066$ PPAR $\gamma$ binding site up-regulated relative luciferase activity against the pGl3-CPTI $\alpha 2 a-1304$. Other mutant vectors, including double 
and triple mutant of PPAR $\gamma$ binding sites, presented no significant difference in luciferase activities against the wild-type pGl3-CPTI $\alpha 2 a-1304$, indicating that the $-1044 /-1066$ PPAR $\gamma$ binding site possibly played a negative regulatory role in CPTI $2 a$ transcription. In addition, disruption of the $-1719 /-1741$ PPAR $\gamma$ binding site reduced the luciferase activity induced by pioglitazone, and disruption of $-1719 /-1741$ PPAR $\gamma$ binding site along with either $-1179 /-1201$ PPAR $\gamma$ binding site or $-1104 /-1136$ PPAR $\gamma$ binding site also reduced the luciferase activity induced by pioglitazone, suggesting that $-1719 /-1741$ PPAR $\gamma$ binding site contributed to the transcriptional response of CPTI $\alpha 2 a$ to pioglitazone. Taken together, these results indicated that PPAR $\alpha$ could not regulate the transcription of CPT I $\alpha 1 b$ and CPT I $\alpha 2 a$ at their predicted binding sites, and the transcription of the grass carp CPT I $2 a$ gene expression could be controlled by PPAR $\gamma$.

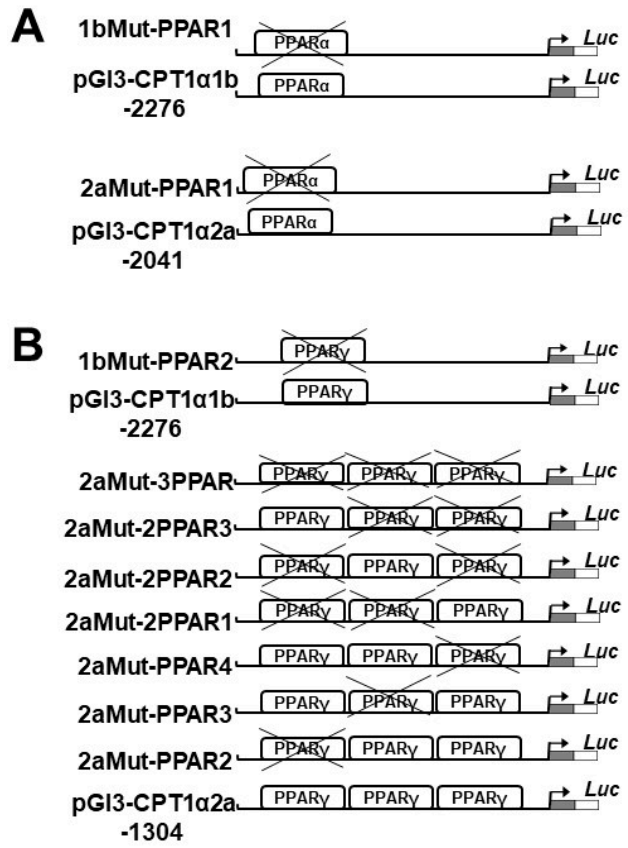

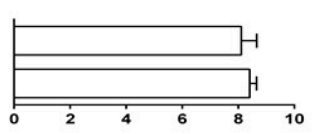

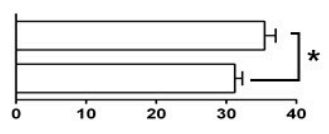

Relative Luciferase Activity
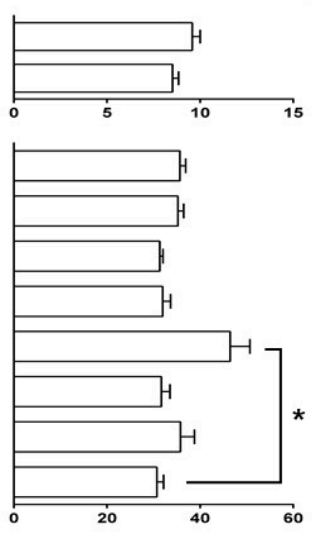

Relative Luciferase Activity
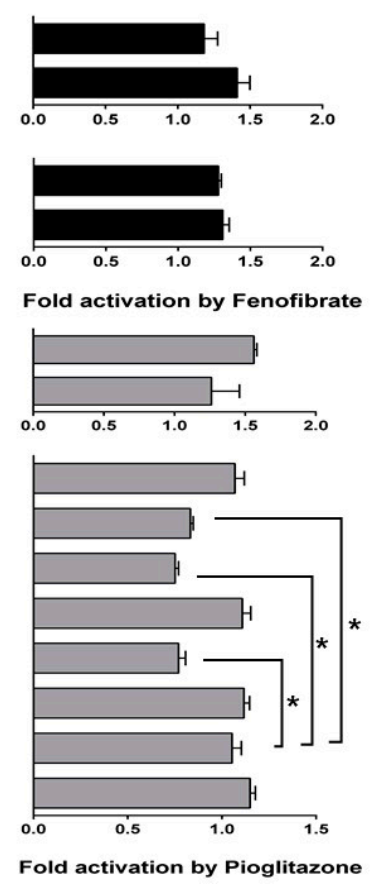

Figure 6. Analysis of putative PPAR binding sites by site-directed mutagenesis. Site-mutation constructs are presented in the left panel. Promoter activity of constructs is presented in the middle. Promoter activity treated with agonist was presented in the right panel. (A) site-mutations of PPAR $\alpha$ binding sites on pG13-CPTI $\alpha 1 b-2276$ and pG13-CPTI $\alpha 2 a-2041$ vectors (B) site-mutation of PPAR $\gamma$ binding sites on pGl3-CPTI $\alpha 1 b-2276$ and pGl3-CPTI $\alpha 2 a-1304$ vectors. Values represent the ratio between firefly and renilla luciferase activities, normalized to the control plasmid pGL3-Basic. Bars are the mean \pm SEM of three independent experiments (Student's $t$-test, $\left.{ }^{*} p<0.05\right)$.

\subsection{EMSA of Each PPAR Binding Sequence}

Having demonstrated that the putative PPAR binding site was important for the transcriptional activities of CPT I $\alpha 1 b$ and CPT I $\alpha 2 a$ genes, we next examined whether PPARs could bind to this site directly. We used EMSA assay to confirm this mechanism (Figure 7). Two close weak bands were observed at the $-1814 /-1836$ PPAR $\alpha$ binding sequence of CPT I $\alpha 1 b$ promoter, and neither a 100-fold excess unlabeled probe nor a 100-fold excess unlabeled point-mutated probe could compete out the labeled probe, indicating that this sequence was not bound by PPAR $\alpha$ (Figure 7A). Only the free probe band was discovered at the $-1719 /-1741$ PPAR $\gamma$ binding sequence of CPT I $\alpha 1 b$ promoter (Figure 7B), suggesting that this sequence was not bound by any transcriptional factors. A strong band close to a weak band was observed at the $-1939 /-1961$ PPAR $\alpha$ binding sequence of CPT I $\alpha 2 a$ promoter, and neither a 100-fold excess unlabeled probe nor a 100-fold excess unlabeled point-mutated probe could compete out the labeled probe, indicating that this sequence was not bound by PPAR $\alpha$ 
(Figure 7C). Similarly, Figure 7D and E also indicated that the $-1179 /-1201$ and $-1104 /-1136$ PPAR $\gamma$ binding sequences of CPT I $\alpha 2 a$ promoter were not bound by PPAR $\gamma$. Only the sequence corresponding to the $-1104 /-1066$ PPAR $\gamma$ binding site of the CPT I $\alpha 2 a$ promoter could bind with proteins from HepG2 nuclear extract (NP) and be disrupted by a 100-fold excess of unlabeled wild-type, and restored by a point-mutant probe (Figure 7F), confirming that -1044/-1066 PPAR $\gamma$ binding site of the CPT $I \alpha 2 a$ promoter could react with PPAR $\gamma$.

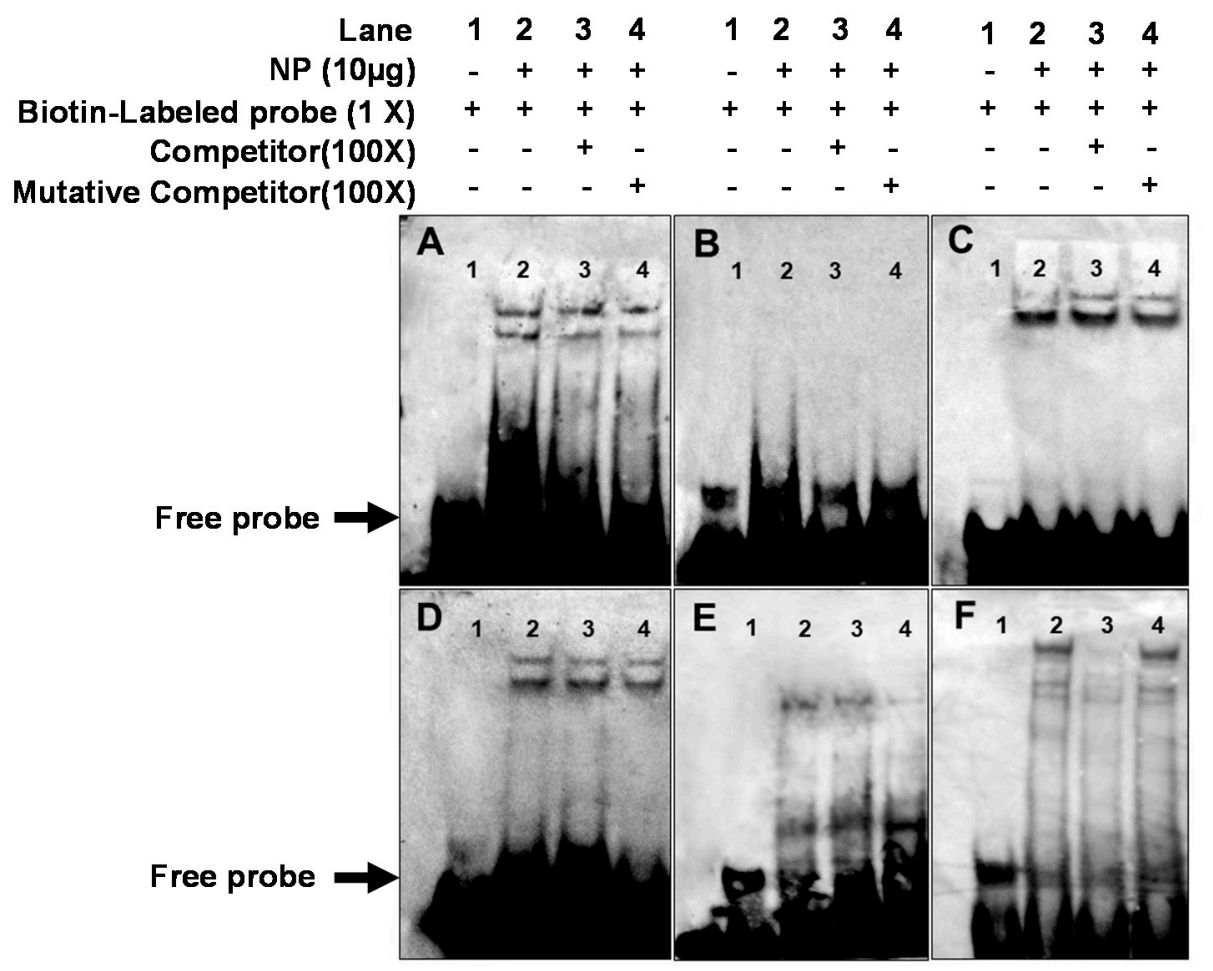

Figure 7. Electrophoretic mobility-shift assay (EMSA) of putative PPAR binding sequences. The 5'-biotin labeled double-stranded oligomers were incubated with HepG2 nuclear extract (NP). A 100-fold excess of the competitor and Mutative competitor oligomers was added to the competition and mutant competition assay, respectively. The oligonucleotide sequences are given in Table 1. (A) PPAR $\alpha /$ RXR binding sequence located at -1814 bp to -1836 bp of CPT I $\alpha 1$ b promoter (B) PPAR $\gamma$ binding sequence located at $-1719 \mathrm{bp}$ to $-1741 \mathrm{bp}$ of CPT I $\alpha 1 b$ promoter (C) PPAR $\alpha / \mathrm{RXR}$ binding sequence located at $-1939 \mathrm{bp}$ to $-1961 \mathrm{bp}$ of CPT I $\alpha 2 a$ promoter (D) PPAR $\gamma$ binding sequence located at $-1179 \mathrm{bp}$ to $-1201 \mathrm{bp}$ of CPT I $\alpha 2 a$ promoter (E) PPAR $\gamma$ binding sequence located at $-1104 \mathrm{bp}$ to -1136 bp of CPT I $2 a$ promoter (F) PPAR $\gamma$ binding sequence located at -1044 bp to -1066 bp of CPT I 2 a promoter.

\section{Discussion}

The reaction catalyzed by CPT I is a rate-controlling step in the pathway of LCFA $\beta$-oxidation. Currently, five isoforms of CPT I genes (CPT I $1 a$, , CPT I $1 \alpha 1 b, C P T I \alpha 2 a, C P T I \alpha 2 b$ and CPT I $\beta$ ) were identified in grass carp (C. idella) $[10,11]$. Moreover, these studies indicated that, compared with other isoforms, mRNA levels of CPT I $1 b$ and CPT $1 \alpha 2 a$ were predominant in the liver. Therefore, CPT I $\alpha 1 b$ and CPT $1 \alpha 2 a$ were considered as the liver isoform. To investigate their transcriptional regulatory mechanism, for the first time, we cloned the sequences of CPT I $\alpha 1 b$ and CPT I $\alpha 2 a$ promoters in fish, and explored their functional characteristics.

In the present study, we found two TSSs of CPT I $\alpha 1 b$ corresponding to the alternative $5^{\prime}$ splice variants of CPT I $\alpha 1 b$ mRNA. Studies suggested that alternative TSSs usually occurred in the proximal promoter of genes lacking TATA and CCAAT boxes [33]. Batarseh et al. [34] pointed out that multiple 
TSSs were typically TATA-less and they were located within CpG islands. Park et al. [19] found that the rat L-CPT I (CPT I $\alpha$ ) promoter was GC rich and TATA-less and had an alternative transcription initiation. However, our present study found some variations in TSSs of the CPT I $\alpha 1 b$ promoter in grass carp. Grass carp CPT I $1 b$ promoter was AT-rich and contained two TATA elements without canonical CPG islands, but DNase I foot printing assay showed that both TATA elements were not protected from DNase I digestion, whereas the INR, which encompassed the TSS, was protected from DNase I digestion. These phenomena indicated that the basal transcription of the CPT I $\alpha 1 b$ gene required the INR to position the basal transcription machinery. In agreement with our study, Smale and Kadonaga [35] pointed out that the INR was located at the TSS and it was independent of, or in synergy with the TATA box. Thus, our results suggested that the basal transcription of the $C P T I \alpha 1 b$ gene might be mediated through an INR-independent mechanism. For CPT I $2 a$ gene, the present study indicated that the core promoter of grass carp CPT I $\alpha 2 a$ was GC-rich and did not contain a TATA box.

In agreement with rat CPT I $\alpha$ gene [21], our study indicated that the proximal promoter region of CPT I $2 a$ contained several Sp1 and NF-Y binding sites, whereas only one transcription initiation was identified on the promoter. Steffen et al. [21] pointed out that the Sp1, Sp3 and NF-Y factors played major roles in driving basal expression of rat CPT I $\alpha$ gene. Sp1, a ubiquitously expressed prototypic $\mathrm{C} 2 \mathrm{H} 2$-type zinc finger protein, can activate or repress transcription after physiological and pathological stimuli $[36,37]$. Studies demonstrated that multiple Sp1 binding sites were a common feature of TATA-less promoters [35]. Moreover, the Sp1 can bind GC-rich motifs and regulate the expression of genes via protein-protein interactions or interplay with other transcription factors and/or components of the transcriptional machinery [37]. NF-Y, one of the major transcriptional factors binding to the CCAAT box, may interact with Sp1 to regulate transcription of various genes [38,39]. In agreement with these studies, the present study indicated that Sp1 and NFY factors were identified on the core region of CPT I $\alpha$ a promoter in a similar manner, indicating a similar transcription initiation for CPT I $\alpha 2 a$ transcription. Taken together, our study indicated that transcription initiation of the $C P T I \alpha 1 b$ and CPT I $2 a$ genes presented different mechanisms, suggesting that the expression of two genes from grass carp was induced by different transcriptional initiation.

Identification of TFBSs is very important for deciphering the mechanisms of gene regulation [40]. To better understand the regulation of CPT I $\alpha 1 b$ and CPT I $\alpha 2 a$ at the transcriptional level, we functionally characterized the CPT I $\alpha 1 b$ and CPT I $\alpha 2 a$ promoters of grass carp. The present study identified a cluster of TFBS, such as TR, HNF4 and PPAR family, on the grass carp CPT I $\alpha 1 b$ and CPT I $\alpha 2 a$ promoters. Similarly, Jackson-Hayes et al. [41] showed that the rat CPT I $\alpha$ gene had a thyroid hormone response element (TRE) which was required for the thyroid hormone receptor (TR) binding. In the present study, several TREs were also observed on the grass carp CPT I $\alpha 1 b$ and $C P T I \alpha 2 a$ promoters. Interestingly, our study found that CPT I $\alpha 1 b$ and CPT I $2 a$ promoters were bound by different isoforms of TRs. The two TREs on the CPT I $\alpha 1 b$ promoter were only for TR $\alpha$ binding, and the three TREs on the CPT I $\alpha 2 a$ promoter were only for TR $\beta$ binding. In fish, TR $\alpha$ and TR $\beta$ were expressed at different developmental stages, suggesting their functional differentiation [42]. Additionally, TR $\alpha$ and TR $\beta$ were differentially regulated by systemic thyroid status in fish [43]. Thus, these studies strongly suggested that the transcriptions of CPT I $\alpha 1 b$ and CPT I $\alpha 2 a$ genes were regulated through different mechanism in the liver.

In the present study, deletion analysis indicated that several regions of the promoters contained a potential cis-active element(s) which enhanced/decreased transcriptional activities of the grass carp $C P T I \alpha 1 b$ and CPT I $2 a$ genes. Furthermore, the regions of the CPT I 1 Ib and CPT I $2 a$ promoters presented different reporter activities in HepG2 and HEK293 cells. Obviously, the enhancing/decreasing reporter activity indicated the existence of potential positive/negative regulators on the regions, respectively. For the promoter of $C P T I \alpha 1 b$ gene, we found that, compared to the region between -1716 and $1379 \mathrm{bp}$, the luciferase activity between the region from $-2276 \mathrm{bp}$ to $-1716 \mathrm{bp}$ significantly increased in HepG2 and HEK293 cells. Interestingly, we noticed that the $-2067 /-2091$ TR $\alpha$ binding 
site, $-1939 /-1961$ PPAR $\alpha$ binding site and $-1719 /-1741$ PPAR $\gamma$ binding site were located at the region from $-2276 \mathrm{bp}$ to $-1716 \mathrm{bp}$, which was reported to correlated with CPT I expression in mammals [41,44-46]. For the promoter of CPT I $22 a$ gene, we discovered that the luciferase activity increased from the TSS to $-848 \mathrm{bp}$ in HepG 2 cells, whereas the activity increased from TSS to $-1165 \mathrm{bp}$ in HEK293 cells, indicating a different regulation at the region from $-848 \mathrm{bp}$ to $-1165 \mathrm{bp}$ between the two kinds of cell lines. In the meantime, we found the $-1103 /-1127$ TR $\beta$ binding site, $-1044 /-1066$ PPAR $\gamma$ binding site and -1104/-1126 PPAR $\gamma$ binding site were located in this region. Besides, the luciferase activity declined at the region from $-1304 \mathrm{bp}$ to $-1646 \mathrm{bp}$ in HepG2 cells, but not in HEK293 cells, and this region contained the $-1331 /-1355$ TR $\beta$ binding site. Considering different TREs on CPT I $\alpha 1 b$ and CPT I $\alpha a$ promoter, TR enhanced the promoter activity of corresponding genes and might play important roles in regulating the expression of CPT I $\alpha 2 a$ in different tissues. Moreover, we also discovered that the luciferase activity declined in the region from $-2695 \mathrm{bp}$ to $-2276 \mathrm{bp}$ of CPT I $\alpha 1 b$ and the region from -1304 bp to -1646 bp of CPT I 2 2a promoter in HepG2 cells. Obviously, some negative regulators binding on these regions regulated $C P T I \alpha 1 b$ and CPT I $2 a$ expression. In addition, studies suggested that the luciferase activity declined in the deletion region from more that $-6000 \mathrm{bp}$ to $-1653 \mathrm{bp}$ on the promoter of rat CPT I $\alpha$ [21]. However, the present study indicated that the transcription activity increased on the upstream of the promoters of grass carp CPT I $\alpha 1 b$ and $C P T I \alpha 2 a$, suggesting that positive regulators existed on the upstream region of CPT I $\alpha 1 b$ and CPT I $\alpha 2 a$ promoters. Thus, it appears that the regulation of CPT I $\alpha 1 b$ and CPT I $\alpha 2 a$ transcription was more complicated in fish than mammals.

PPARs are key transcriptional factors which mediate the regulation of many enzymes related with lipid metabolism [44]. Studies suggested that CPT I was one of the target genes of PPAR $\alpha$ [27,45]. In our study, the activities of CPT I $\alpha 1 b$ and CPT I $\alpha 2 a$ promoters were induced by fenofibrate, PPAR $\alpha$ agonist. However, site-directed mutagenesis and EMSA analysis indicated that CPT I $\alpha 1 b$ and CPT I $\alpha 2 a$ were not regulated through those predicted PPAR $\alpha$ binding sites. Accordingly, the reporter activities were up-regulated by fenofibrate, indicating that other potential PPAR $\alpha$ binding sites or other related factors existed on the promoter. For instance, studies suggested that PPAR $\alpha$-induced activation of CP I $\alpha$ gene was enhanced in a ligand-dependent manner by PGC-1 [46], and PGC-1, as a co-activator, can activate gene transcription through HNF4 $\alpha$ [47]. Additionally, studies established the necessity of the first intron in the transcriptional regulation of the CPT I $\alpha$ gene $[26,40]$. Taken together, the induction of CPT I $\alpha 1 b$ and CPT I $2 a$ by fenofibrate may involve several nuclear factors and/or other promoter regions of the gene.

PPAR $\gamma$ is one of transcriptional factors which plays important roles in lipogenesis. The present study indicated that transcription of grass carp CPT I was regulated by PPAR $\gamma$. Pioglitazone, the agonist of PPAR $\gamma$ [48], could increase the activity of grass carp CPT I $\alpha 2 a$ promoter, and site-mutation on the $-1044 /-1066$ PPAR $\gamma$ binding site reduced the activity. Moreover, EMSA assay confirmed that the sequence at $-1044 \mathrm{bp}$ to $-1066 \mathrm{bp}$ was a functional binding locus. Similarly, Gilde et al. [49] found that overexpression of PPAR $\gamma$ in cardiomyocytes was accompanied by basal and ligand-activated transcription of the CPT I promoter. Patsouris et al. [50] reported that PPAR $\gamma$ compensated for PPAR $\alpha$ by mediating the HFD-induced up-regulation of PPAR $\alpha$ target genes involved in fatty acid oxidation in PPAR $\alpha$-null mice. Moreover, studies suggested that the addition of a classical agonist ligand promoted the dissociation of the co-repressor and the binding of co-activator proteins resulting in an enhancement in the basal transcriptional level of specific genes [51,52]. Stanley [53] found that the PPAR $\gamma$-directed pioglitazone enhanced the affinity for co-activators and decreased the affinity for co-repressor on PPAR $\gamma$, indicating that PPAR $\gamma$ possibly activated gene transcription by causing the dissociation of co-repressors and promoting the association of co-activator proteins. Similarly, the present study indicated that site-directed mutagenesis on the $-1044 /-1066$ PPAR $\gamma$ binding site possibly decreased the activity of CPT I $\alpha 2 a$ promoter, and pioglitazone-induced activation of PPAR $\gamma$ could up-regulate the activity of CPT I $\alpha 2 a$ promoter. These evidences indicated that PPAR $\gamma$ probably 
played an important role in regulating CPT I $\alpha 2$ a transcription and compensated for PPAR $\alpha$-induced expression of lipolytic genes in fish.

In summary, the 2695-bp CPT I $\alpha 1 b$ and 2631-bp CPT I $\alpha 2 a$ promoters in grass carp had been cloned and characterized. The promoters of CPT I $1 b$ and CPT I $\alpha 2 a$ genes showed the different structures in their core regions. Several putative TFBSs had been predicted in their promoter regions. Analysis of $5^{\prime}$ deletion mutants presented the regulatory characteristics of CPT I $\alpha 1 b$ and CPT I $\alpha 2 a$ promoters. Fenofibrate activated the activities of CPT I $\alpha 1 b$ and CPT I $\alpha 2 a$ promoters. PPAR $\gamma$ played an important role in regulating CPT I expression. The present study provided new insights into the regulatory mechanisms of liver isoforms of CPT I genes in fish.

\section{Materials and Methods}

\subsection{Experimental Animals and Cells}

Juvenile grass carp was obtained from Hubei Honghu Fisheries Farm (Jingzhou, Hubei Province, China). HepG2 and HEK293 cell lines were obtained from the Cell Resource Center in Fishery College of Huazhong Agricultural University. We ensured that the experiments were performed in accordance with the experimental protocols of Huazhong Agricultural University (HZAU) and approved by the ethics committee of HZAU (identification code: Fish-2015-0324, Date: 24 March 2015).

\subsection{Rapid Amplification of $5^{\prime} c D N A$ Ends (5' RACE)}

The TSSs of CPT I $1 b$ and CPT I $2 a$ genes were determined using the GeneRacer Kit (Invitrogen, Carlsbad, CA, USA), according to the manufacturer's instructions. Briefly, total RNA was isolated from the liver tissue using TRIzol Reagent (Invitrogen), and then the $5^{\prime}$-ready cDNA libraries were prepared using reverse transcription kit (Invitrogen). Nested PCR was performed using a commercial nested $5^{\prime}$ primer (Invitrogen) in combination with a reverse gene-specific primer complementary to CPT I $\alpha 1 b$ and CPT I $2 a$ genes. The PCR reactions were performed using TaKaRa PrimeSTAR ${ }^{\circledR} \mathrm{HS}$ DNA Polymerase kit (TaKaRa, Otsu, Japan) under the following PCR conditions: pre-incubation at $94{ }^{\circ} \mathrm{C}$ for $3 \mathrm{~min}, 30$ cycles of $94^{\circ} \mathrm{C}$ for $15 \mathrm{~s}, 60^{\circ} \mathrm{C}$ for $30 \mathrm{~s}$ and $72{ }^{\circ} \mathrm{C}$ for $1 \mathrm{~min}$. Amplified PCR products were gel-purified and subcloned into pMD19-T for sequencing (Tsingke, Wuhan, China).

\subsection{Cloning of Promoter and Plasmid Construction}

Based on the published draft genome of grass carp [32], we cloned the sequences of $C P T I \alpha 1 b$ and CPT I $2 a$ promoters. Genomic DNA was extracted from grass carp tail fins using a commercial kit (Omega, Norcross, GA, USA). For amplification of the CPT $I \alpha 1 b$ and $C P T$ I $2 a$ promoter sequences, specific primers with overlapping sequence were designed and listed in Table 1. For the generation of the luciferase reporter constructs, the PCR product and pGl3-Basic vectors (Promega, Madison, WI, USA) were purified and digested using corresponding endonucleases, and then products were ligated using ClonExpress ${ }^{\mathrm{TM}}$ II One Step Cloning Kit (Vazyme, Piscataway, NJ, USA). According to the distance from its TSS, the plasmids were named as pGl3-CPTI $\alpha 1 b-2695$ and pGl3-CPTI $\alpha 2 a-2632$, respectively. Plasmids pGl3-CPTI $\alpha 1 b-2276$, pGl3-CPTI $\alpha 1 b-1716$, pGl3-CPTI $\alpha 1 b-1073$, pGl3-CPTI $\alpha 1 b-581$, pGl3-CPTI $\alpha 1 b-86$, pGl3-CPTI $\alpha 2 a-2041$, pGl3-CPTI $\alpha 2 a-1646$, pGl3-CPTI $\alpha 2 a-1304$, pGl3-CPTI $\alpha 2 a-1165$, pGl3-CPTI $\alpha 2 a-848$, pGl3-CPTI $\alpha 2 a-428$ and pGl3-CPTI $\alpha 2 a-97$, which contained unidirectional deletions of the promoter regions, were generated with the Erase-a-Base system (Promega) using templates of pGl3-CPTI $\alpha 1 b-2695$ and pGl3-CPTI $\alpha 2 a-2632$, respectively. The PCR reactions were performed using TaKaRa PrimeSTAR ${ }^{\circledR}$ HS DNA Polymerase kit (TaKaRa) as mentioned above. All plasmids were sequenced in a commercial company (Tsingke). 
Table 1. Primers used in the experiments.

\begin{tabular}{|c|c|c|}
\hline Name & Primer & Sequence $\left(5^{\prime}-3^{\prime}\right)$ \\
\hline \multicolumn{3}{|c|}{ Primers for promoter construct } \\
\hline \multirow{2}{*}{ CPT I $\alpha 1 b$} & $+36 \mathrm{R}$ & CCСAAGCTTCTAACAATTCCGATGATGTGG \\
\hline & $-2695 \mathrm{~F}$ & CGAGCTCAAGCAAGAAGGCAATAGGGT \\
\hline \multirow[t]{2}{*}{ CPT I $2 a$} & $+30 \mathrm{R}$ & CCCAAGCTTCGTGCCTTTGATACTAAGTGCG \\
\hline & $-2631 \mathrm{~F}$ & CGAGCTCGGGCTACCAGTAACTATAAGGG \\
\hline \multicolumn{3}{|c|}{ Primers for deleting PPAR binding sites of promoters } \\
\hline \multirow{4}{*}{ 1bMut } & - PPAR1F & GCACTTTTCTTTTCCAGAATTTTGTAGTTGTGAGTCA \\
\hline & - PPAR1R & CTGGAAAAGAAAAGTGCCTTTAATTTCTTGCTC \\
\hline & - PPAR2F & TGTAGTGGCGACATCTCAGTATCATCTGGGTGG \\
\hline & - PPAR2R & TGAGATGTCGCCACTACAGGGAGGTGGAAAGGG \\
\hline \multirow{8}{*}{ 2aMut } & - PPAR1F & GTTTTACAATTTGTTGGAAATTTTGTTTTGTTTAATG \\
\hline & - PPAR1R & TCCAACAAATTGTAAAACAAGCATTGCCAACAA \\
\hline & - PPAR2F & GACTTCGGTAACACTAACAAAACAGTGGGGTAAATC \\
\hline & - PPAR2R & GTTAGTGTTACCGAAGTCAACATTCTCACATTG \\
\hline & - PPAR3F & ATGCTCACCGAACAGCTTATGTAAGGCAAGGGA \\
\hline & - PPAR3R & AAGCTGTTCGGTGAGCATGGAACAGGATTTACC \\
\hline & - PPAR4F & GGAAGGGGTGATGGAAAAAATCTGTGGTGTCTG \\
\hline & - PPAR4R & TTTTCСАТСАССССТТСССТТGССТТАСАTAAG \\
\hline \multicolumn{3}{|c|}{ Oligonucleotide for EMSA assay } \\
\hline \multirow{2}{*}{$\begin{array}{l}\text { CPT I } 1 b \\
\text { - PPAR1 }\end{array}$} & Biotin-probe & Biotin-TAAGCAACTTTGCACTGATTTAC \\
\hline & Mutative-competitor & TAAGCAACCCCCCACTGATTTAC \\
\hline \multirow{2}{*}{$\begin{array}{l}\text { CPT I } 1 b \\
\text { - PPAR2 }\end{array}$} & Biotin-probe & Biotin-ATTTGTTCTTTCCCCCAATGGCC \\
\hline & Mutative-competitor & ATTTGTTCCCCCCCCCAATGGCC \\
\hline \multirow[t]{2}{*}{$\begin{array}{l}\text { CPT I } 2 a \\
\text { - PPAR1 }\end{array}$} & Biotin-probe & Biotin-CGATCAACTATTTCATAGTTGTT \\
\hline & Mutative-competitor & CGATCAAGGGGTTCATAGTTGTT \\
\hline \multirow{2}{*}{$\begin{array}{l}\text { CPT I } 2 a \\
\text { - PPAR2 }\end{array}$} & Biotin-probe & Biotin-AATAATTGTGGGAAAGGTGAAAG \\
\hline & Mutative-competitor & AATAATTGTGGGGGGGGTGAAAG \\
\hline \multirow{2}{*}{$\begin{array}{l}\text { CPT I } 2 a \\
\text { - PPAR3 }\end{array}$} & Biotin-probe & Biotin-TCTTGCTGTGAAATAGGTCAGTT \\
\hline & Mutative-competitor & TCTTGCTGTGAAGGGGGTCAGTT \\
\hline \multirow[t]{2}{*}{$\begin{array}{l}\text { CPT I } 2 a \\
\text { - PPAR3 }\end{array}$} & Biotin-probe & Biotin-GGCTGGGTGGTCTTTTCCCACTT \\
\hline & Mutative-competitor & GGCCCCCTGGTCTTTTCCCACTT \\
\hline \multicolumn{3}{|c|}{ Primer for DNase I foot printing assay } \\
\hline & M13F & GTAAAACGACGGCCAGT \\
\hline & M13R-FAM & FAM-CAGGAAACAGCTATGAC \\
\hline
\end{tabular}

\subsection{Sequence Analysis}

For sequence analysis of promoters of CPT I $\alpha 1 b$ and CPT I $\alpha 2 a$ genes in grass carp, putative TFBSs were predicted by MatInspector online (http:/ /www.genomatix.de/). Nucleotide sequences of CPT $I \alpha 1 b$ and CPT I 2 a promoters were compared with DNA sequences present in the GenBank database (http:/ /www.ncbi.nlm.nih.gov/genbank/) and the UCSC Genome Browser (http://genome.ucsc.edu/). 


\subsection{DNase I Foot Printing Assay}

DNase I foot printing assays were performed based on the method of Zianni et al. [54]. In brief, 303-bp and 346-bp proximal regions of CPT I $\alpha 1 b$ promoter, which contained two TSSs (TSS1 and TSS2, respectively), were PCR amplified and cloned into pMD-19T vector (TaKaRa). Then, the amplicons were used as the template for further preparation of fluorescent 6-carboxy-fluorescein (FAM)-labeled probes with M13F and M13R-FAM to label the coding strand. After agarose gel electrophoresis, the FAM-labeled probes were purified by Gel Extraction Kit (Omega, USA) and quantified with NanoDrop 2000 (Thermo, Waltham, MA, USA). $10 \mu \mathrm{g}$ of proteins extracted from HepG2 cell lines were incubated with $500 \mathrm{ng}$ of probes in the same binding buffer based on Zianni et al. [53]. DNase I digestion was performed for $3 \mathrm{~min}$ at room temperature and then terminated by the addition of DNase I stop solution (Promega). Digested samples were precipitated with alcohol and then analyzed with the 3730 DNA Analyzer in the commercial company (Tsingke).

\subsection{Transfections and Luciferase Assays}

HepG2 and HEK293 cells were cultured in DMEM medium supplemented with $10 \%(v / v)$ heat-inactivated FBS (Invitrogen) and $2 \mathrm{mM}$ L-glutamine in a humidified atmosphere with $5 \% \mathrm{CO}_{2}$ at $37^{\circ} \mathrm{C}$. Prior to the transient transfection, HepG2 or HEK293 cells were seeded in 24-well cell culture plate at a density of $1.2 \times 10^{5}$ and cultured for $24 \mathrm{~h}$ to reach $70-80 \%$ convergence. Plasmids were transiently transfected into HepG2 or HEK293 cells using Lipofectamine ${ }^{\mathrm{TM}} 2000$ (Invitrogen) following the manufacture's protocol. All reporter plasmids were used in equimolar amounts in Opti-MEM (Invitrogen), and they were co-transfected with $35 \mathrm{ng}$ pRL-TK as the control. After $4 \mathrm{~h}$, the transfection medium was replaced by $10 \%$ FBS-DMEM. Then, with 24-h incubation, cells were harvested to assay the relative luciferase activity by Dual-Luciferase Reporter Assay System (Promega). The relative luciferase activity was presented as the ratio of firefly luciferase to renilla luciferase. Results were normalized to the control reporter pGl3-Basic. All experiments were performed in triplicates and measured at least three times.

\subsection{Site-Mutation Analysis of PPAR Binding Sites on the Grass Carp CPT I $\alpha 1 b$ and CPT I $\alpha 2 a$ Promoters}

To identify the corresponding PPAR binding sites on the grass carp CPT I $\alpha 1 b$ and CPT I $2 a$ promoters, we performed site-directed mutagenesis according to the manufacture instruction of QuickChange II Site-Directed Mutagenesis Kit (Vazyme). pGl3-CPTI $\alpha 1 b-2276$, pGl3-CPTI $\alpha 2 a-2041$ and pGl3-CPTI $\alpha 2 a-1304$ were used as templates. The mutagenesis primers were listed in Table 1 , and the PCR reactions were performed as mentioned above. These mutant constructs were named as 1bMut-PPAR1, 1bMut-PPAR2, 2aMut-PPAR1, 2aMut-PPAR2, 2aMut-PPAR3, 2aMut-PPAR4, 2aMut-2PPAR1, 2aMut-2PPAR2, 2aMut-2PPAR3 and 2aMut-3PPAR, respectively. Then the constructs and pRL-TK were co-transfected into HepG2 cell lines using Lipofectamine ${ }^{\mathrm{TM}} 2000$ following the manufacture's protocol. After $4 \mathrm{~h}$, the transfection medium was replaced by $10 \%$ FBS-DMEM with $50 \mu \mathrm{M}$ fenofibrate or $10 \mu \mathrm{M}$ pioglitazone. After 24-h incubation, cells were harvested to assay the luciferase activity according to the procedure above.

\subsection{Electrophoretic Mobility-Shift Assay (EMSA)}

EMSA was performed to confirm the functional PPAR binding sites of the promoters. Proteins for EMSA were extracted from HepG2 cell lines. Nuclear and cytoplasmic extracts were prepared based on the methods of Read et al. [55]. Protein concentrations were determined by the BCA method [56]. These extracts were stored at $-20{ }^{\circ} \mathrm{C}$ until analyzed. Each oligonucleotide duplex of PPAR binding sites was incubated with $10 \mu \mathrm{g}$ nuclear extracts at room temperature according to the instruction of LightShift ${ }^{\mathrm{TM}}$ Chemiluminescent EMSA Kit (Invitrogen), and each unlabeled probe was pre-incubated $10 \mathrm{~min}$ prior to the addition of biotin-labeled probe. The reaction was allowed to proceed for $30 \mathrm{~min}$ after the addition of biotin-labeled probe at room temperature, and then were 
detected by electrophoresis on $6 \%$ native polyacrylamide gels. Competition analyses were performed by using 100-fold excess of unlabeled oligonucleotide duplex with or without the mutation. All the oligonucleotide sequences of EMSA were listed in Table 1.

\subsection{Statistical Analysis}

Results were presented as mean \pm SEM (standard errors of means) in at least three independent biological experiments. Prior to statistical analysis, all data were tested for normality of distribution using the Kolmogornov-Smirnov test. Differences between wild types and drug-treated groups were compared using the Student's $t$ test. Difference was considered significant at $p<0.05$. All statistical analyses were performed using the SPSS10.0 for Windows (SPSS, Michigan Avenue, Chicago, IL, USA).

Acknowledgments: This work was supported by the Fundamental Research Funds for the Central Universities, China (Grants Nos. 2014JQ002, 2662015PY017).

Author Contributions: Zhi Luo and Yi-Huan Xu designed the experiment; Yi-Huan Xu conducted the experiment with the help of Kun Wu, Yao-Fang Fan, Wen-Jing You and Li-Han Zhang; Yi-Huan Xu, Kun Wu and Zhi Luo analyzed the data; Yi-Huan Xu drafted the manuscript and Zhi Luo revised the manuscript. All the authors read and approved the manuscript.

Conflicts of Interest: The authors declare no conflicts of interest with the contents of this article.

\section{Abbreviations}

$\begin{array}{ll}\text { CPT I } & \text { carnitine palmitoyltransferase I } \\ \text { FAM } & \text { fluorescent 6-carboxy-fluorescein } \\ \text { L-CPT } & \text { liver carnitine palmitoyltransferase } \\ \text { LCFA } & \text { long-chain fatty acid } \\ \text { M-CPT } & \text { muscle carnitine palmitoyltransferase } \\ \text { PCR } & \text { polymerase chain reaction } \\ \text { PPAR } & \text { peroxisome proliferator-activated receptor } \\ \text { PPRE } & \text { peroxisome proliferator-responsive element } \\ \text { RLM-5'RACE } & \text { RNA ligase-mediated rapid amplification of } 5^{\prime} \text { cDNA ends } \\ \text { RXR } & \text { retinoid X receptor } \\ \text { TFBS } & \text { transcription factor binding site } \\ \text { TR } & \text { thyroid hormone receptor } \\ \text { TRE } & \text { thyroid hormone response elements }\end{array}$

\section{References}

1. Sargent, J.R.; Tocher, D.R.; Bell, J.G. The lipids. In Fish Nutrition, 2nd ed.; Halver, J., Hardy, R., Eds.; Academic Press: New York, NY, USA; San Diego, CA, USA, 2002; pp. 181-257.

2. Bartlett, K.; Eaton, S. Mitochondrial $\beta$-oxidation. FEBS J. 2004, 271, 462-469. [CrossRef]

3. Skiba-Cassy, S.; Collin, A.; Chartrin, P.; Médale, F.; Simon, J.; Duclos, M.J.; Tesseraud, S. Chicken liver and muscle carnitine palmitoyltransferase 1: Nutritional regulation of messengers. Comp. Biochem. Physiol. B 2007, 147, 278-287. [CrossRef] [PubMed]

4. Morash, A.J.; Kajimura, M.; McClelland, G.B. Intertissue regulation of carnitine palmitoyltransferase I (CPTI): Mitochondrial membrane properties and gene expression in rainbow trout (Oncorhynchus mykiss). BBA-Biomembr. 2008, 1778, 1382-1389. [CrossRef] [PubMed]

5. Britton, C.H.; Schultz, R.A.; Zhang, B.; Esser, V.; Foster, D.W.; McGarry, J.D. Human liver mitochondrial carnitine palmitoyltransferase I: Characterization of its cDNA and chromosomal localization and partial analysis of the gene. Proc. Natl. Acad. Sci. USA 1995, 92, 1984-1988. [CrossRef] [PubMed]

6. Yamazaki, N.; Shinohara, Y.; Shima, A.; Yamanaka, Y.; Terada, H. Isolation and characterization of cDNA and genomic clones encoding human muscle type carnitine palmitoyltransferase I. BBA-Gene Struct. Expr. 1996, 1307, 157-161. [CrossRef] 
7. Price, N.T.; van der Leij, F.R.; Jackson, V.N.; Corstorphine, C.G.; Thomson, R.; Sorensen, A.; Zammit, V.A. A novel brain-expressed protein related to carnitine palmitoyltransferase I. Genomics 2002, 80, 433-442. [CrossRef] [PubMed]

8. Zheng, J.L.; Luo, Z.; Zhu, Q.L.; Chen, Q.L.; Gong, Y. Molecular characterization, tissue distribution and kinetic analysis of carnitine palmitoyltransferase I in juvenile yellow catfish Pelteobagrus fulvidraco. Genomics 2013, 101, 195-203. [CrossRef] [PubMed]

9. Wu, K.; Zheng, J.L.; Luo, Z.; Chen, Q.L.; Zhu, Q.L. Carnitine palmitoyltransferase I gene in Synechogobius hasta: Cloning, mRNA expression and transcriptional regulation by insulin in vitro. Gene 2016, 576, 429-440. [CrossRef] [PubMed]

10. Hu, W. Isolation, Purification, Cloning, Kinetic Properties of Enzymes Related to Lipid Metabolism and Response to Copper and Zinc in Ctenopharyngodon idella. Ph.D. Dissertation, Huazhong Agricultural University, Wuhan, China, 2015.

11. Shi, X.C.; Sun, J.; Yang, Z.; Li, X.X.; Ji, H.; Li, Y.; Chang, Z.G.; Du, Z.Y.; Chen, L.Q. Molecular characterization and nutritional regulation of carnitine palmitoyltransferase (CPT) family in grass carp (Ctenopharyngodon idellus). Comp. Biochem. Physiol. 2017, 203, 11-19. [CrossRef] [PubMed]

12. McGarry, J.D.; Brown, N.F. The mitochondrial carnitine palmitoyltransferase system: From concept to molecular analysis. Eur. J. Biochem. 1997, 244, 1-14. [CrossRef] [PubMed]

13. Boukouvala, E.; Leaver, M.J.; Favre-Krey, L.; Theodoridou, M.; Krey, G. Molecular characterization of a gilthead sea bream (Sparus aurata) muscle tissue cDNA for carnitine palmitoyltransferase 1B (CPT 1B). Comp. Biochem. Physiol. 2010, 157, 189-197. [CrossRef] [PubMed]

14. Zheng, J.L.; Hu, W.; Luo, Z.; Zhao, Y.H.; Zhu, Q.L.; Li, X.D. Comparative study on the kinetic behaviour of carnitine palmitoyltransferase I between Javelin goby Synechogobius hasta (carnivorous) and grass carp Ctenopharyngodon idella (herbirovous). Aquacult. Nutr. 2013, 19, 665-676. [CrossRef]

15. Plagnes-Juan, E.; Lansard, M.; Seiliez, I.; Médale, F.; Corraze, G.; Kaushik, S.; Panserat, S.; Skiba-Cassy, S. Insulin regulates the expression of several metabolism-related genes in the liver and primary hepatocytes of rainbow trout (Oncorhynchus mykiss). J. Exp. Biol. 2008, 211, 2510-2518. [CrossRef] [PubMed]

16. Morash, A.J.; Bureau, D.P.; McClelland, G.B. Effects of dietary fatty acid composition on the regulation of carnitine palmitoyltransferase (CPT) I in rainbow trout (Oncorhynchus mykiss). Comp. Biochem. Physiol. 2009, 152, 85-93. [CrossRef] [PubMed]

17. Polakof, S.; Médale, F.; Skiba-Cassy, S.; Corraze, G.; Panserat, S. Molecular regulation of lipid metabolism in liver and muscle of rainbow trout subjected to acute and chronic insulin treatments. Domest. Anim. Endocrin. 2010, 39, 26-33. [CrossRef] [PubMed]

18. Zheng, J.L.; Luo, Z.; Hu, W.; Liu, C.X.; Chen, Q.L. Differential effects of dietary Zn deficiency and excess on carnitine status, kinetics and expression of CPT I in yellow catfish Pelteobagrus fulvidraco. Aquaculture 2014, 420-421, 10-17. [CrossRef]

19. Chen, Q.L.; Luo, Z.; Liu, C.X.; Zheng, J.L. Differential effects of dietary Cu deficiency and excess on carnitine status, kinetics and expression of CPT I in liver and muscle of yellow catfish Pelteobagrus fulvidraco. Comp. Biochem. Physiol. 2015, 188, 24-30. [CrossRef] [PubMed]

20. Park, A.E.; Steffen, L.M.; Song, S.; Park, M.V.; Cook, A.G. Cloning and characterization of the promoter for the liver isoform of the rat carnitine palmitoyltransferase I (L-CPT I) gene. Biochem. J. 1998, 330, 217-224. [CrossRef] [PubMed]

21. Steffen, M.L.; Harrison, W.R.; Elder, F.F. Expression of the rat liver carnitine palmitoyltransferase I (CPT-I $\alpha)$ gene is regulated by Sp1 and nuclear factor Y: Chromosomal localization and promoter characterization. Biochem. J. 1999, 340, 425-432. [CrossRef] [PubMed]

22. Mascaró, C.; Acosta, E.; Ortiz, J.A.; Marrero, P.F.; Hegardt, F.G.; Haro, D. Control of human muscle-type carnitine palmitoyltransferase I gene transcription by peroxisome proliferator-activated receptor. J. Biol. Chem. 1998, 273, 8560-8563. [CrossRef] [PubMed]

23. Leone, T.C.; Weinheimer, C.J.; Kelly, D.P. A critical role for the peroxisome proliferator-activated receptor $\alpha$ $(\operatorname{PPAR} \alpha)$ in the cellular fasting response: The PPAR $\alpha$-null mouse as a model of fatty acid oxidation disorders. Proc. Natl. Acad. Sci. USA 1999, 96, 7473-7478. [CrossRef] [PubMed]

24. Ribet, C.; Montastier, E.; Valle, C.; Bezaire, V.; Mazzucotelli, A.; Mairal, A.; Viguerie, N.; Langin, D. Peroxisome proliferator-activated receptor- $\alpha$ control of lipid and glucose metabolism in human white adipocytes. Endocrinology 2010, 151, 123-133. [CrossRef] [PubMed] 
25. Zheng, J.L.; Zhuo, M.Q.; Luo, Z.; Song, Y.F.; Pan, Y.X.; Huang, C.; Hu, W.; Chen, Q.L. Peroxisome proliferator-activated receptor alpha1 in yellow catfish Pelteobagrus fulvidraco: Molecular characterization, mRNA tissue expression and transcriptional regulation by insulin in vivo and in vitro. Comp. Biochem. Physiol. 2015, 183, 58-66. [CrossRef] [PubMed]

26. Hsu, S.C.; Huang, C.J. Changes in liver PPAR $\alpha$ mRNA expression in response to two levels of high-safflower-oil diets correlate with changes in adiposity and serum leptin in rats and mice. J. Nutr. Biochem. 2007, 18, 86-96. [CrossRef] [PubMed]

27. Napal, L.; Marrero, P.F.; Haro, D. An intronic peroxisome proliferator-activated receptor-binding sequence mediates fatty acid induction of the human carnitine palmitoyltransferase 1A. J. Mol. Biol. 2005, 354, 751-759. [CrossRef] [PubMed]

28. Song, S.; Attia, R.R.; Connaughton, S.; Niesen, M.I.; Ness, G.C.; Elam, M.B.; Hori, R.T.; Cook, G.A.; Park, E.A. Peroxisome proliferator activated receptor $\alpha(\operatorname{PPAR} \alpha)$ and PPAR gamma coactivator (PGC-1 $\alpha)$ induce carnitine palmitoyltransferase IA (CPT-1A) via independent gene elements. Mol. Cell. Endocrinol. 2010, 325, 54-63. [CrossRef] [PubMed]

29. Zheng, J.L.; Zhuo, M.Q.; Luo, Z.; Pan, Y.X.; Song, Y.F.; Huang, C.; Zhu, Q.L.; Hu, W.; Chen, Q.L. Peroxisome proliferator-activated receptor gamma (PPAR $\gamma$ ) in yellow catfish Pelteobagrus fulvidraco: Molecular characterization, mRNA expression and transcriptional regulation by insulin in vivo and in vitro. Gen. Comp. Endocr. 2015, 212, 51-62. [CrossRef] [PubMed]

30. Chen, X.; Feng, Y.; Yang, W.J.; Shu, G.; Jiang, Q.Y.; Wang, X.Q. Effects of dietary thiazolidinedione supplementation on growth performance, intramuscular fat and related genes mRNA abundance in the longissimus dorsi muscle of finishing pigs. Asian Australas. J. Anim. 2013, 26, 1012. [CrossRef] [PubMed]

31. Opuszynski, K.; Shireman, J.V. Herbivorous Fishes: Culture and Use for Weed Management; CRC Press Inc.: Boca Raton, FL, USA, 1995.

32. Wang, Y.; Lu, Y.; Zhang, Y.; Ning, Z.; Li, Y.; Zhao, Q.; Lu, H.; Huang, R.; Xia, X.; Feng, Q.; et al. The draft genome of the grass carp (Ctenopharyngodon idellus) provides insights into its evolution and vegetarian adaptation. Nat. Genet. 2015, 47, 625-631. [CrossRef] [PubMed]

33. Valen, E.; Sandelin, A. Genomic and chromatin signals underlying transcription start-site selection. Trends Genet. 2011, 27, 475-485. [CrossRef] [PubMed]

34. Batarseh, A.; Barlow, K.D.; Martinez-Arguelles, D.B.; Papadopoulos, V. Functional characterization of the human translocator protein $(18 \mathrm{kDa})$ gene promoter in human breast cancer cell lines. BBA-Gene Regul. Mech. 2012, 1819, 38-56. [CrossRef] [PubMed]

35. Smale, S.T.; Kadonaga, J.T. The RNA polymerase II core promoter. Annu. Rev. Biochem. 2003, 72, 449-479. [CrossRef] [PubMed]

36. Suske, G. The Sp-family of transcription factors. Gene 1999, 238, 291-300. [CrossRef]

37. Wierstra, I. Sp1: Emerging roles-beyond constitutive activation of TATA-less housekeeping genes. Biochem. Biophys. Res. Commun. 2008, 372, 1-13. [CrossRef] [PubMed]

38. Bolognese, F.; Pitarque-Martì, M.; Cicero, V.L.; Mantovani, R.; Maier, J.A. Characterization of the human EDF-1 minimal promoter: Involvement of NFY and Sp1 in the regulation of basal transcription. Gene 2006, 374, 87-95. [CrossRef] [PubMed]

39. Sun, F.; Xie, Q.; Ma, J.; Yang, S.; Chen, Q.; Hong, A. Nuclear factor Y is required for basal activation and chromatin accessibility of fibroblast growth factor receptor 2 promoter in osteoblast-like cells. J. Biol. Chem. 2009, 284, 3136-3147. [CrossRef] [PubMed]

40. Chan, T.M.; Leung, K.S.; Lee, K.H. TFBS identification based on genetic algorithm with combined representations and adaptive post-processing. Bioinformatics 2007, 24, 341-349. [CrossRef] [PubMed]

41. Jackson-Hayes, L.; Song, S.; Lavrentyev, E.N.; Jansen, M.S.; Hillgartner, F.B.; Tian, L.; Wood, P.A.; Cook, G.A.; Park, E.A. A thyroid hormone response unit formed between the promoter and first intron of the carnitine palmitoyltransferase-I $\alpha$ gene mediates the liver-specific induction by thyroid hormone. J. Biol. Chem. 2003, 278, 7964-7972. [CrossRef] [PubMed]

42. Liu, Y.W.; Lo, L.J.; Chan, W.K. Temporal expression and T3 induction of thyroid hormone receptors $\alpha 1$ and $\beta 1$ during early embryonic and larval development in zebrafish, Danio rerio. Mol. Cell. Endocrinol. 2000, 159, 187-195. [CrossRef] 
43. Johnson, K.M.; Lema, S.C. Tissue-specific thyroid hormone regulation of gene transcripts encoding iodothyronine deiodinases and thyroid hormone receptors in striped parrotfish (Scarus iseri). Gen. Comp. Endocrinol. 2011, 172, 505-517. [CrossRef] [PubMed]

44. Reddy, J.K., III. Peroxisomal $\beta$-oxidation, PPAR $\alpha$, and steatohepatitis. Am. J. Physiol. 2001, 281, G1333-G1339.

45. Lawrence, J.W.; Li, Y.; Chen, S.; DeLuca, J.G.; Berger, J.P.; Umbenhauer, D.R.; Moller, D.E.; Zhou, G. Differential gene regulation in human versus rodent hepatocytes by peroxisome proliferator-activated receptor (PPAR) $\alpha$ : PPAR $\alpha$ fails to induce peroxisome proliferation-associated genes in human cells independently of the level of receptor expression. J. Biol. Chem. 2001, 276, 31521-31527. [CrossRef] [PubMed]

46. Koo, S.H.; Satoh, H.; Herzig, S.; Lee, C.H.; Hedrick, S.; Kulkarni, R.; Evans, R.M.; Olefsky, J.; Montminy, M. PGC-1 promotes insulin resistance in liver through PPAR- $\alpha$-dependent induction of TRB-3. Nat. Med. 2004, 10, 530-534. [CrossRef] [PubMed]

47. Yoon, J.C.; Puigserver, P.; Chen, G.; Donovan, J.; Wu, Z.; Rhee, J.; Adelmant, G.; Stafford, J.; Kahn, C.R.; Granner, D.K.; et al. Control of hepatic gluconeogenesis through the transcriptional coactivator PGC-1. Nature 2001, 413, 131-138. [CrossRef] [PubMed]

48. Lehmann, J.M.; Moore, L.B.; Smith-Oliver, T.A.; Wilkison, W.O.; Willson, T.M.; Kliewer, S.A. An antidiabetic thiazolidinedione is a high affinity ligand for peroxisome proliferator-activated receptor $\gamma$ (PPAR $\gamma$ ). J. Biol. Chem. 1995, 270, 12953-12956. [CrossRef] [PubMed]

49. Gilde, A.J.; van der Lee, K.A.; Willemsen, P.H.; Chinetti, G.; van der Leij, F.R.; van der Vusse, G.J.; Staels, B.; van Bilsen, M. Peroxisome proliferator-activated receptor (PPAR) $\alpha$ and PPAR $\beta / \delta$, but not PPAR $\gamma$, modulate the expression of genes involved in cardiac lipid metabolism. Circ. Res. 2003, 92, 518-524. [CrossRef] [PubMed]

50. Patsouris, D.; Reddy, J.K.; Muller, M.; Kersten, S. Peroxisome proliferator-activated receptor $\alpha$ mediates the effects of high-fat diet on hepatic gene expression. Endocrinology 2006, 147, 1508-1516. [CrossRef] [PubMed]

51. Xu, L.; Glass, C.K.; Rosenfeld, M.G. Coactivator and corepressor complexes in nuclear receptor function. Curr. Opin. Genet. Dev. 1999, 9, 140-147. [CrossRef]

52. Robyr, D.; Wolffe, A.P.; Wahli, W. Nuclear hormone receptor coregulators in action: Diversity for shared tasks. Mol. Endocrinol. 2000, 14, 329-347. [CrossRef] [PubMed]

53. Stanley, T.B.; Leesnitzer, L.M.; Montana, V.G.; Galardi, C.M.; Lambert, M.H.; Holt, J.A.; Xu, H.E.; Moore, L.B.; Blanchard, S.G.; Stimmel, J.B. Subtype specific effects of peroxisome proliferator-activated receptor ligands on corepressor affinity. Biochemistry 2003, 42, 9278-9287. [CrossRef] [PubMed]

54. Zianni, M.; Tessanne, K.; Merighi, M.; Laguna, R.; Tabita, F.R. Identification of the DNA bases of a DNase I footprint by the use of dye primer sequencing on an automated capillary DNA analysis instrument. J. Biomol. Tech. 2006, 17, 103-113. [PubMed]

55. Read, M.A.; Cordle, S.R.; Veach, R.A.; Carlisle, C.D.; Hawiger, J. Cell-free pool of CD14 mediates activation of transcription factor NF-kappa B by lipopolysaccharide in human endothelial cells. Proc. Natl. Acad. Sci. USA 1993, 90, 9887-9891. [CrossRef] [PubMed]

56. Smith, P.K.; Krohn, R.I.; Hermanson, G.T.; Mallia, A.K.; Gartner, F.H.; Provenzano, M.; Fujimoto, N.M.; Goeke, B.J.; Olson, B.J.; Klenk, D.C. Measurement of protein using bicinchoninic acid. Anal. Biochem. 1985, 150, 76-85. [CrossRef]

(C) 2017 by the authors. Licensee MDPI, Basel, Switzerland. This article is an open access article distributed under the terms and conditions of the Creative Commons Attribution (CC BY) license (http:// creativecommons.org/licenses/by/4.0/). 